\title{
A new method for testing thermal shock resistance properties of soapstone - Effects of microstructures and mineralogical variables
}

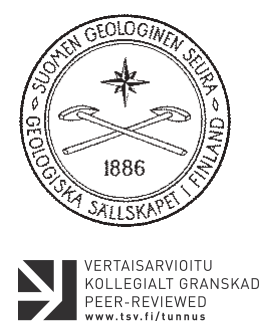

\author{
Anne Huhta ${ }^{{ }^{*}}$, Aulis Kärki ${ }^{2}$ and Eero Hanski ${ }^{\mathrm{I}}$ \\ ${ }^{1}$ Oulu Mining School, University of Oulu, P.O. Box 3000, 90014 University of Oulu, \\ Finland \\ ${ }^{2}$ Kivitieto Oy, Teknologiantie 1, 90590 Oulu, Finland
}

\begin{abstract}
Soapstone industry utilizes different types of soapstone mainly as a construction material for fireplaces. In this application soapstone has to meet different temperature requirements in different parts of fireplaces. Mineralogical and structural information is needed for placing an appropriate type of soapstone in an appropriate position in the fireplace construction. This allows employment of higher temperatures resulting in more particulate-free combustion, which makes it possible for soapstone industry to develop more efficient and environmentally friendly fireplaces.

Of many soapstone types, which differ from each other in their chemical composition and thermal properties, carbonate soapstone and its microstructural variations were investigated in this study. A new method was developed to measure thermal shock resistant of natural stones. By exposing carbonate soapstone samples of different textural types to rapid temperature changes, it was possible to determine the parameters that affect the capacity of the rock to resist thermal shock.

The results indicate that the type of microtexture is an important factor in controlling the thermal shock resistance of carbonate soapstone. The soapstone samples with a high thermal shock resistance show deformation textures, such as crenulation cleavage and S/C mylonite. A strong negative correlation was observed between the thermal shock resistance and length of cleavage domains in foliated rocks. Also a slight elevation in the iron concentration of talc and magnesite was discovered to improve the thermal shock resistance of carbonate soapstone. Attention should especially be paid to the length and planarity of cleavage domains of spaced foliation.
\end{abstract}

Keywords: Crenulation cleavage; Microstructure; Soapstone; S/C mylonite; Texture; Thermal shock resistance

*Corresponding author e-mail: anne.huhta@oulu.fi

Editorial handling: Jussi S. Heinonen (jussi.s.heinonen@helsinki.fi) 


\section{Introduction}

Soapstones are low- to medium-grade metamorphic rocks, which have been formed via different metamorphic and carbonate metasomatic processes. Their potential protoliths, i.e. original pre-metamorphic rock types, are either ultramafic igneous rocks, mostly representing ophiolitic mantle rocks (e.g., Lindahl \& Nilsson, 2008) and komatiitic olivine-rich cumulates (e.g., Eckstrand, 1975), or magnesium-rich carbonate sediments (e. g., Piniazkiewicz et al., 1994).

Soapstones show a large variation in mineral compositions and microstructures. In general, they are thought to comprise $>35 \%$ of talc, $>25 \%$ of chlorite, and varying amounts of quartz, calcite, dolomite, magnesite, tremolite, amphiboles, and hematite (Kuzvart, 1984). However, Kärki et al. (2008) proposed a more detailed classification scheme which is based on the relative quantities and absolute volumes of the main minerals in soapstones and suggest that the amount of talc in rocks classified as soapstones should be between $30-70 \%$. In addition to the minerals mentioned above, soapstones can occasionally contain micas and relicts of mafic minerals, such as olivine and pyroxene, formed by magmatic or metamorphic processes. Locally, oxide and sulfide minerals also form a substantial part of the volume of soapstone. The most significant of these minerals are magnetite, chromite, pyrrhotite, chalcopyrite, and pyrite.

Since prehistoric times, soapstone has been known as a raw material for different utility articles and for their good durability at high temperatures (Storemyr, 2004). Nowadays, soapstone industry utilizes soapstone mainly as a construction material for fireplaces. The material used in fireplace construction has to meet the requirements of different heat conditions. Some components on the outer surface of the fireplaces warm only up $70{ }^{\circ} \mathrm{C}$, whereas other parts are exposed to combustion gases with temperatures exceeding $1000^{\circ} \mathrm{C}$. Mineralogical and structural information is needed for placing an appropriate soapstone type in an appropriate position in the fireplaces. Proper construction allows the use of higher temperatures, resulting in more particulate-free combustion, and this in turn makes it possible for soapstone industry to develop more efficient and more environmentally friendly fireplaces.

Soapstones are much more resistant to thermal shock than most other natural stone materials, but there are no generally acknowledged test methods for natural stone under high-temperature conditions. The existing methods that are standardized in different countries have been mostly designed for testing ceramic materials or natural stones that are intended to be used under cool conditions (Appendix A). Our studies have shown that these tests are poorly functional or totally unsuitable for testing fireplace materials. For this reason, a method that determinates the thermal shock resistance of natural stone material in a wide temperature range has been developed by modifying the method described in standard DIN 51068. This method can be used for measuring the thermal shock resistance (TSR) for any natural stones, but in particular for soapstones at temperatures up to $1200^{\circ} \mathrm{C}$. The most functional and appropriate method to determine the thermal shock resistance of soapstone is based on heating the material in an electric kiln and cooling it down rapidly in a water medium.

Using soapstone samples from the Nunnanlahti area, eastern Finland (Fig. 1), the aim of this study was to introduce a new method for determining thermal shock resistance of soapstones and to examine how the microstructures and mineralogical variables of carbonate soapstone contribute to the capacity of soapstone to resist thermal shock. This was done by exposing soapstone specimens with different mineralogical and textural characteristics to rapid temperature changes and converting these thermal shock results to values which are comparable to each other regardless of the temperature of the experiments. 


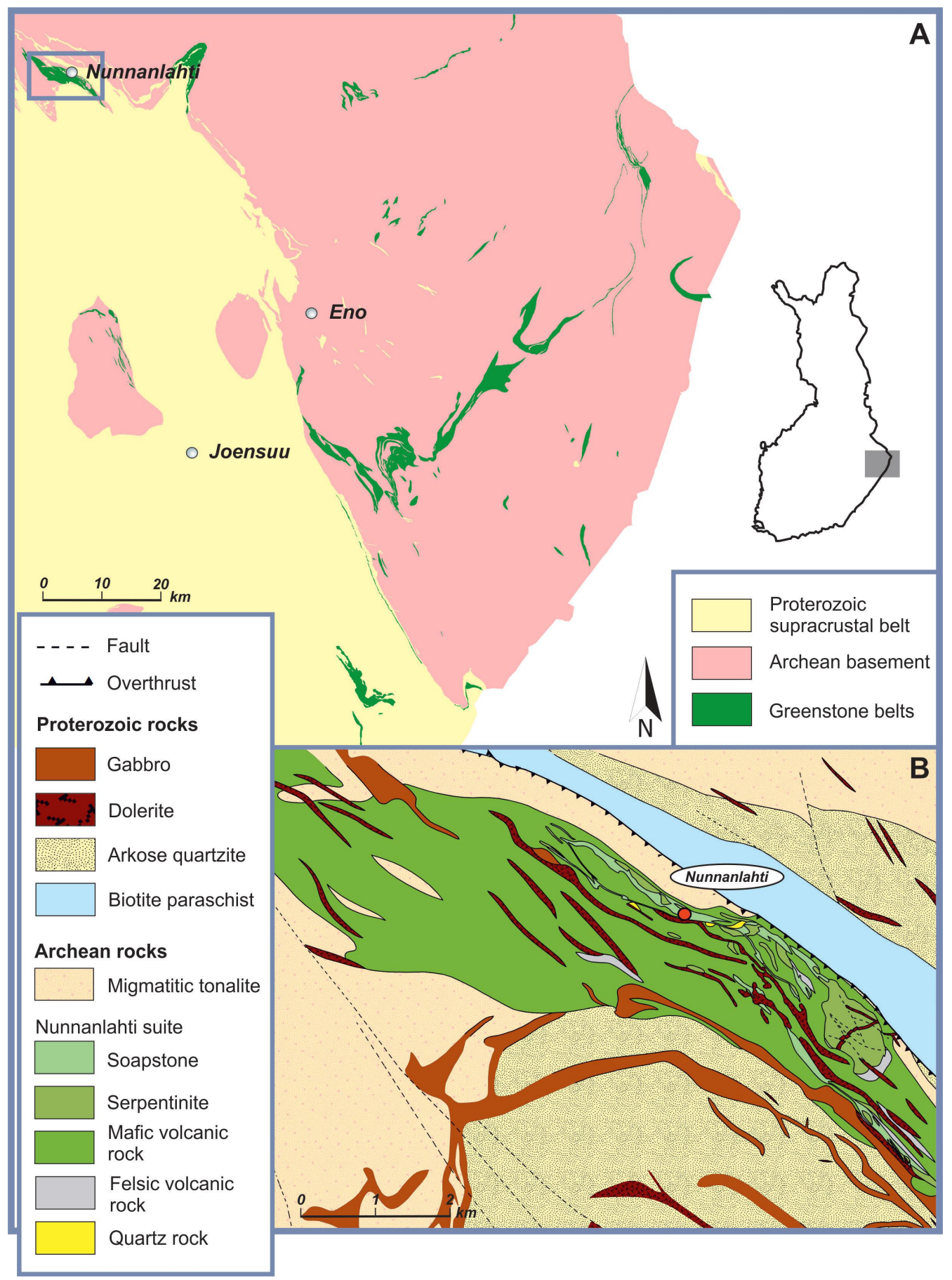

Fig. 1. Regional distribution of greenstone belts in Northern Karelia, Finland (A). Location of the Kärenvaara soapstone massif with Nunnanlahden Uuni mine (red dot) and geological environment of the investigated Eastern soapstone massives (B). Modified after Geological Survey of Finland, 2015. 


\section{Soapstones in the Nunnanlahti area}

The study location is situated in the Nunnanlahti area in Juuka, eastern Finland (Fig. 1). The economic potential of the Nunnanlahti soapstone deposits was recognized already in the late 19th century and already by the turn of the century, soapstone was widely used in the ornate facades of many public buildings (Rossi, 1997). In the 1960's, the production of dimension stone ceased entirely at Nunnanlahti, but the quarrying operations were resumed in the 1980's, when soapstone fireplaces and ovens became fashionable in Central Europe. In 2014, the total amount of soapstone excavated from four quarries in the Nunnanlahti area was around 180000 tons (Finnish Safety and Chemicals Agency, 2014).

Among the first geological studies of the ultramafic rocks in the area are those by Haapala (1936) and Wiik (1953). More recently, the mineralogy, geochemistry and metamorphism of the Nunnanlahti rocks were studied by Wennerstrand (2000) and Lipponen (2000). Soapstone and associated serpentinite lenses occur in a small Archean greenstone belt $15 \mathrm{~km}$ in length and up to $2.5 \mathrm{~km}$ in width (Fig. 1), which is composed mostly of basaltic metavolcanic rocks (Pekkarinen et al., 2006). The belt is bordered by Archean granitoids and Paleoproterozoic metasedimentary rocks and cut by Paleoproterozoic mafic dikes. The ultramafic rocks form 50 - to 250-m-wide (rarely $700 \mathrm{~m}$ ) lens-shaped bodies. Originally they were dunites, which were thoroughly serpentinized and later partly altered to talc-carbonate rocks. There are several soapstone quarries within a distance of $2 \mathrm{~km}$ close to the margin of the greenstone belt, lying on the hanging wall side of the Nunnanlahti Shear zone.

The samples studied in this work were collected from the Nunnanlahden Uuni soapstone mine (Fig. 1). Several different soapstone types with talc and magnesite as the main minerals can be recognized in the Kärenvaara soapstone massif. They differ from each other both by their microstructure and mineral composition. The mine belongs to the NW-SE-trending Kärenvaara soapstone massif with a length of $1.4 \mathrm{~km}$ and maximum width of $0.7 \mathrm{~km}$. The massif is in contact with mafic and felsic volcanic rocks in the west and serpentinite and mafic volcanic rock in the east. At the tectonic contact between soapstone and mafic volcanic rock, there is a metasomatic 0.3 - to 0.5 -m-wide blackwall reaction zone, which is composed of biotite and chlorite (Kojonen, 1986; Wennerstrand, 2000).

\section{Material and methods}

\subsection{Sampling}

The carbonate soapstone samples chosen for this study represent one of the many soapstone types used by the soapstone fireplace manufacturers in Europe. The soapstone samples were collected from detailed profiles across one of the soapstone quarries. The aim was to gather samples which represent as many textural types as possible. Sampling was done with a portable drill in the quarry and also from diamond drill cores.

\subsection{Petrography}

Before subjecting the soapstone samples to thermal shock experiments, thin sections cut perpendicular to the regional $\mathrm{S}_{2}$ foliation were prepared from the sample slabs. They were studied using a Zeiss Axioplan 2 polarization microscope in order to determine the mineralogical composition and types of microstructures in the samples. The modal mineral compositions were determined by the point counting method using 500 points per thin section. Dimensions of five hundred grains were also measured from each thin section. In classification of grain size boundaries, instructions of IUGS-SCMR were followed (Winter, 2014). 


\subsection{Mineralogical studies}

Microstructural and chemical analysis of minerals in thin sections of natural soapstone samples were performed at the Center of Microscopy and Nanotechnology (CMNT), University of Oulu, using a Jeol JXA-8200 electron probe microanalyzer (15 kV accelerating voltage, $10 \mathrm{nA}$ beam current, spot size $2 \mu \mathrm{m})$. Microstructural features and chemical compositions of minerals were determined by using the back-scattered electron (BSE) image mode and wavelength dispersive X-ray spectroscopy (WDS), respectively. In addition, microstructures of some of the samples that were exposed to the thermal shock resistant tests were studied by the energy-dispersive X-ray spectroscopy (EDS) using a Zeiss Ultra Plus field emission scanning electron microscope (FESEM).

\subsection{Thermal shock resistance testing}

The method used to determine the thermal shock resistance of different soapstone types is in many respects based on the existing standard DIN 51068, which is intended for ceramic materials (DIN 51068, Testing of ceramic materials, 1976). Soapstone is a natural material and therefore its texture and chemical composition are widely variable. This poses certain requirements for the method. The measurements have to be conducted over an eligible and extensive temperature range instead of just one instructed temperature. The new test method developed for this purpose was named the Water Cooling Test (WCT). The applicability of the method was tested more than 2000 times following the procedure described below (Kärki et al., 2013):

1. A cylindrical specimen of carbonate soapstone with a diameter of $52 \mathrm{~mm}$ and a height of $50 \mathrm{~mm} \pm 2 \mathrm{~mm}$ was dried at $110 \pm 5^{\circ} \mathrm{C}$ in a hot cabinet (Memmert, maximum heating capacity $220^{\circ} \mathrm{C}$ ) for at least eight hours.

2. After drying, the specimen was heated in an electric furnace (Nabertherm $\mathrm{N} 50$, maximum heating capacity $1200{ }^{\circ} \mathrm{C}$ with Program Controller C7) for 15 minutes. The temperature was set at $600-1100{ }^{\circ} \mathrm{C}$ depending on the type and structure of the soapstone sample. By developing the test Kärki et al. (2013) found that chlorite or carbonate rich soapstones broked down at the lowest test temperatures, whereas the specimens rich in serpentine withstood thermal stress throughout the $1100{ }^{\circ} \mathrm{C}$ contitions. In addition, they noticed that e.g. banding, porphyroblastic texture and very large grain size also lead to an early break down of the samples.

3. Cooling was implemented by plunging the specimen directly from the furnace into running water at $5-10^{\circ} \mathrm{C}$ for 3 minutes.

4. In the next stage, the specimen was placed back to the hot cabinet to be dried for 30 minutes.

5. The heating-cooling-drying cycle described above was repeated for each specimen as long as it broke down into two or more pieces. The test was discontinued if the specimen remained intact after 30 test runs. In that case, the test was continued by raising the heating temperature by $100^{\circ} \mathrm{C}$.

6. The result of the test is the TSW number, which is the number of heating-coolingdrying cycles which the material withstands without breaking down. For tests made at different temperatures, the results were converted to values using the chart constructed by Kärki (2013) (Fig. 2). A separate curve in this chart was composed by exposing one material type to different temperatures and finally the chart was finished with determinations made from several different material types. Based on this chart the result of a single test (TSWnumber) can be converted to a TSR-number, which describes material's capability to resist thermal shock. This way the results received in different temperatures are comparable to each other. 


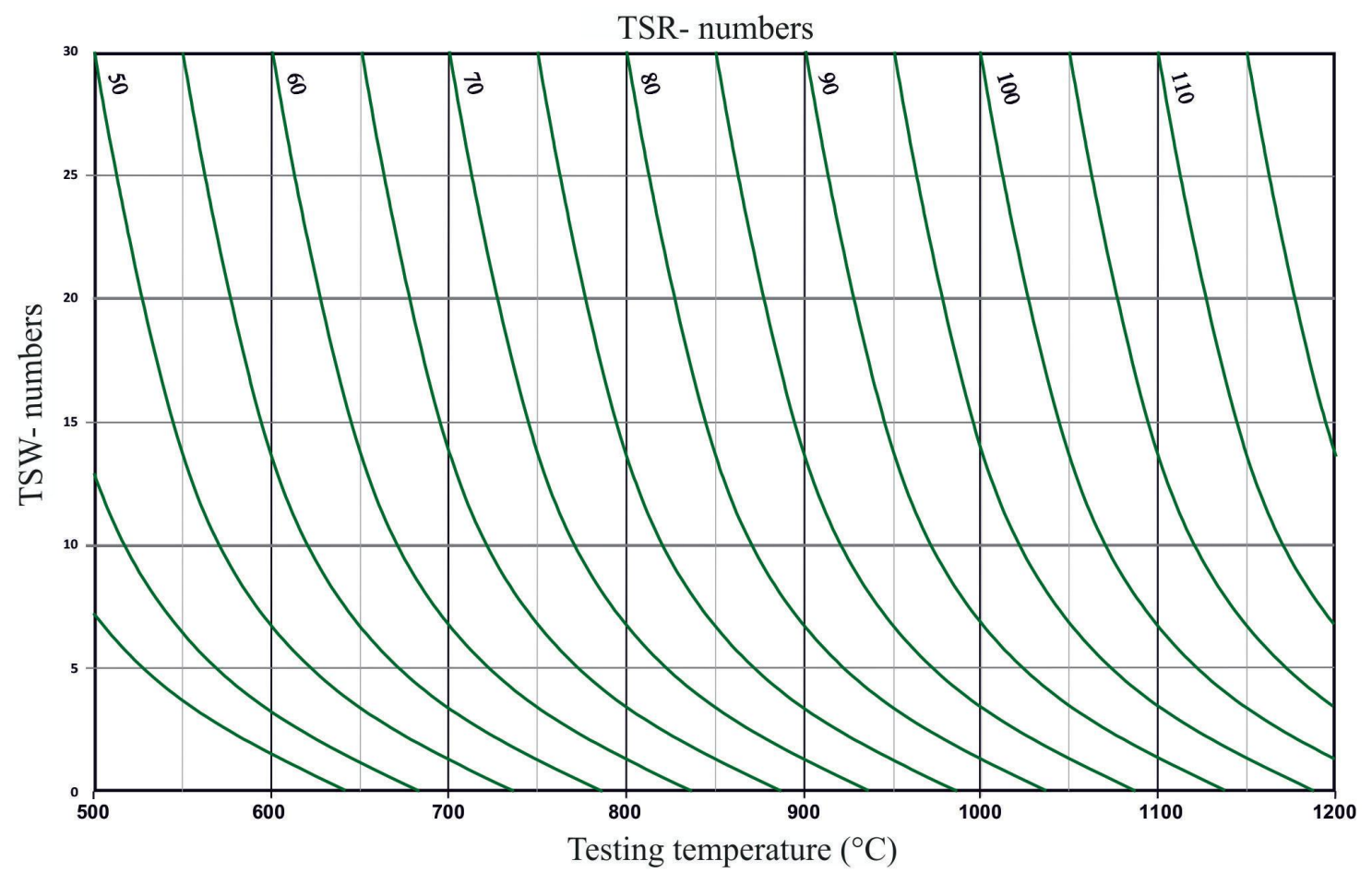

Fig. 2. Chart used to convert TSW numbers to TSR numbers.

If the material was homogeneous, it was possible to obtain exactly the same results for five specimens by using the same test parameters. Only those test series were accepted as successful in which the standard deviation for the TSW number in the test series representing one testing temperature was 3 at maximum. The TSR number describes capacity of the material to withstand rapid temperature changes and it was determined by calculating an average TSW number from at least five test cylinders. Suitability of other cooling mediums related to TSR of soapstone has been studied by Havela (2010) and Pohjola (2013). These other alternatives they described are also functional, but they are more time consuming and require much greater contribution than water cooling test.

\section{Results}

\subsection{Material characterization}

By definition after Kärki et al. 2008, soapstone contains $30-70 \%$ of talc. The modal mineral compositions in the samples of this study are shown in Fig. 3 and listed in Table 1. Main minerals and their percentages in the studied samples are talc (42-61\%) and carbonate (29-50\%) and hence they can be classified as carbonate soapstones according to the classification scheme proposed by Kärki et al., 2008 (Fig. 4). Small amounts of sulfides and oxides (2.2-12.8\%) were also identified, of which the most significant are magnetite, chromite, pyrrhotite, chalcopyrite, and pyrite. Chlorite may also be an abundant mineral in soapstones, but the chlorite content in the selected specimens is only between 0 and $5.4 \%$. The proportions of amphiboles and serpentine (from 0 to $0.4 \%$ ) do not exceed $5 \%$ in the studied samples. 


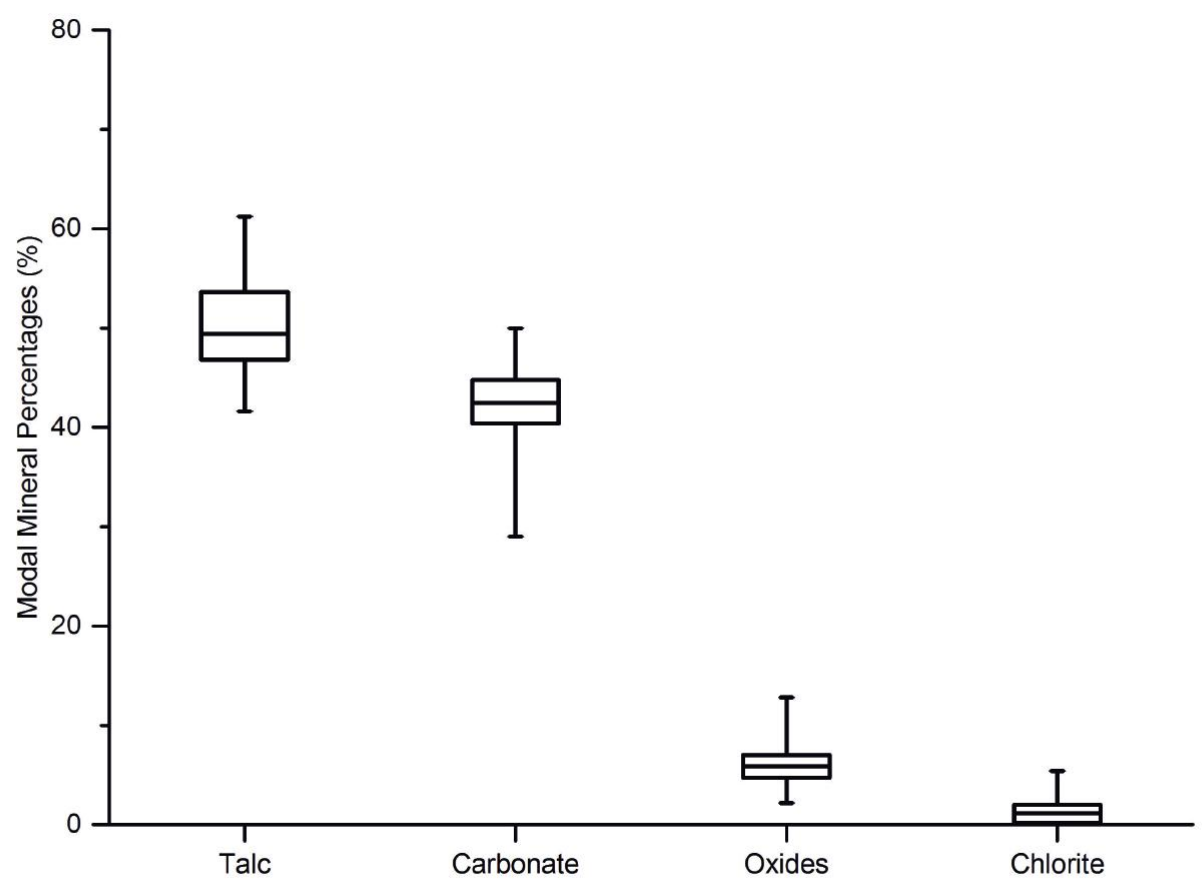

Fig. 3. Box and whisker diagram of mineral modes in the studied samples, showing average, minimum and maximum values of each mineral percentages. The boxes represent lower and upper quartiles of the mineral composition data.

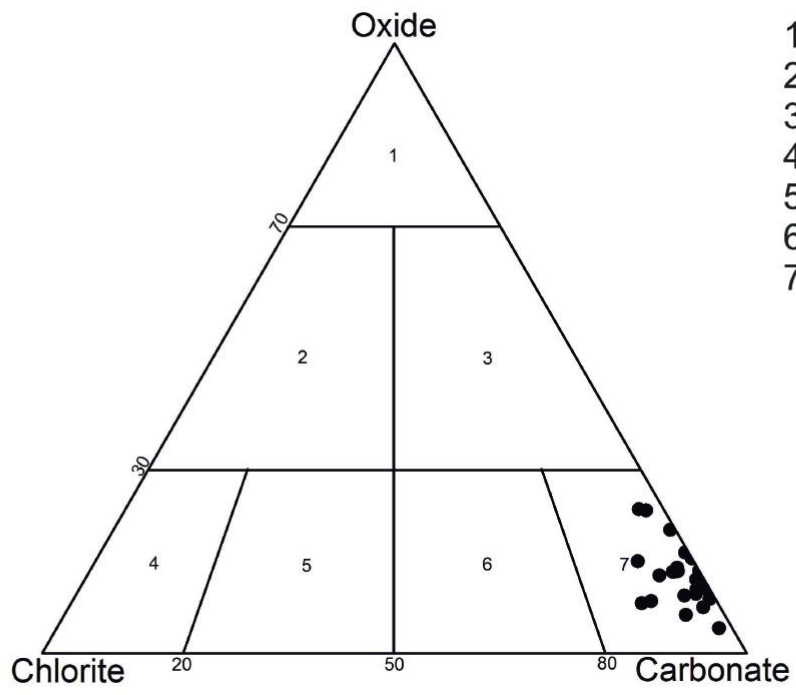

1. Oxide soapstone

2. Oxide chlorite soapstone

3. Oxide carbonate soapstone

4. Chlorite soapstone

5. Carbonate chlorite soapstone

6. Chlorite carbonate soapstone

7. Carbonate soapstone

Fig. 4. Modes of studied samples on a classification diagram of soapstones (Kärki et al. 2008), which is based on the relative abundances of oxides, chlorite and carbonate, when the percentage of hard silicates (olivine, pyroxene, serpentine, amphiboles) stays below $5 \%$. 
A. Huhta, A. Kärki and E. Hanski

Table 1. Modal mineral compositions (volume percentage) of carbonate soapstones according to the results of microscopic analysis.

\begin{tabular}{|c|c|c|c|c|c|c|c|c|}
\hline Sample & Talc & Carbonate & Serpentine & Chlorite & Oxides & Sulfides & Others & Total \\
\hline MH-01 & 41.6 & 47.8 & - & 5.4 & 4.4 & 0.6 & 0.2 & 100.0 \\
\hline MH-02 & 44.6 & 48.2 & - & 1.0 & 5.3 & 0.5 & 0.4 & 100.0 \\
\hline MH-03 & 44.8 & 40.4 & - & 1.4 & 12.8 & - & 0.6 & 100.0 \\
\hline MH-04 & 45.2 & 47.2 & - & 0.6 & 6.3 & 0.3 & 0.4 & 100.0 \\
\hline MH-05 & 46.2 & 44.6 & - & 2.0 & 6.9 & 0.3 & - & 100.0 \\
\hline MH-06 & 46.6 & 50.0 & - & 1.0 & 2.2 & - & 0.2 & 100.0 \\
\hline MH-07 & 46.8 & 43.2 & - & 3.2 & 6.6 & 0.2 & - & 100.0 \\
\hline MH-08 & 46.9 & 45.7 & 2.2 & 0.2 & 4.9 & 0.1 & - & 100.0 \\
\hline MH-09 & 47.0 & 40.8 & - & 4.2 & 7.5 & 0.5 & - & 100.0 \\
\hline MH-10 & 47.2 & 43.4 & - & 2.0 & 6.7 & 0.3 & 0.4 & 100.0 \\
\hline MH-11 & 47.6 & 41.4 & - & 0.4 & 10.3 & 0.3 & - & 100.0 \\
\hline MH-12 & 48.0 & 43.4 & - & 1.6 & 6.8 & 0.2 & - & 100.0 \\
\hline MH-13 & 49.2 & 44.8 & - & 2.8 & 2.9 & 0.3 & - & 100.0 \\
\hline MH-14 & 49.6 & 45.2 & - & 1.2 & 3.7 & 0.1 & 0.2 & 100.0 \\
\hline MH-15 & 50.4 & 44.4 & - & 0.4 & 4.3 & 0.1 & 0.4 & 100.0 \\
\hline MH-16 & 51.0 & 40.4 & - & 1.4 & 6.5 & 0.3 & 0.4 & 100.0 \\
\hline MH-17 & 51.7 & 42.5 & - & 1.1 & 4.5 & 0.2 & - & 100.0 \\
\hline MH-18 & 52.0 & 42.5 & - & - & 5.4 & - & 0.1 & 100.0 \\
\hline MH-19 & 52.8 & 41.8 & - & 0.2 & 4.6 & 0.4 & 0.2 & 100.0 \\
\hline $\mathrm{MH}-20$ & 53.6 & 39.0 & - & 0.0 & 6.9 & 0.3 & 0.2 & 100.0 \\
\hline MH-21 & 53.8 & 37.4 & - & 5.0 & 3.6 & 0.2 & - & 100.0 \\
\hline MH-22 & 54.4 & 41.2 & - & - & 4.3 & 0.1 & - & 100.0 \\
\hline MH-23 & 56.0 & 38.0 & - & - & 5.8 & 0.2 & - & 100.0 \\
\hline $\mathrm{MH}-24$ & 59.0 & 36.0 & - & - & 4.4 & 0.4 & 0.2 & 100.0 \\
\hline MH-25 & 60.2 & 29.0 & - & 1.4 & 8.8 & 0.6 & - & 100.0 \\
\hline MH-26 & 61.2 & 32.2 & - & 0.2 & 6.1 & 0.3 & - & 100.0 \\
\hline
\end{tabular}

The texture is the result of the origin and tectonic history of the rock and is defined by the size, shape and spatial arrangement of mineral grains. (McPhie et al., 1993; Bucher \& Frey, 1994). The texture of the studied carbonate soapstone samples varies from nearly isotropic to extremely foliated. A foliation plane is a surface with a high number of phase boundaries with similar orientation that may interact as a flaw (Åkesson et al., 2003). Foliation of all the studied samples can be categorized as spaced foliation, and thus the rock consists of microlithons and cleavage domains (Passchier \& Trouw, 2005). Microlithons of the foliated soapstones are relicts of the ultramafic protoliths. Cleavage domains are planar layers of elongate carbonate grains and talc scales with microscopic to pervasive planes of contiguous grain boundaries. (Fig. 5) In contrast, microlithons contain a greater amount of equidimensional grains. Textures, like previous foliations, can still be remained in the microlithons. 
Most of the studied carbonate soapstone specimens show crenulation cleavage in some intensity, but there are also other types of textures. Based on the grain size, the foliation can be called crenulation cleavage or crenulation schistosity. The former applies to fine-grained carbonate soapstones up to the scale where individual mineral grains can be seen with the naked eye. Based on our observations, microtextures in the soapstones can be divided into the following five groups:

1. Granoblastic, very fine-grained, limiting diameter $0.01 \mathrm{~mm}$ (VG) texture. Carbonates are equidimensional, talc is randomly orientated, and no clear pervasive foliation can be seen (Fig 6a). Magnetite occurs mainly as euhedral grains and forms thin $(0.03 \mathrm{~mm})$ banding. The average grain size is $<0.1 \mathrm{~mm}$. This texture was recognized in one specimen (Table 2).

2. S/C mylonites (S/C) are protomylonites and they are composed of less than $50 \%$ of matrix produced by dynamic crystallization with a mylonitic foliation (Wise et al., 1984). The mylonitic carbonate soapstones studied express a C-type shear band cleavage, which consists of $S$ planes oriented from upper right to lower left corner transected by planar C-type shear bands occurring as horizontal in Figs. $6 \mathrm{~b}$ and $6 \mathrm{c}$. All the carbonate soapstones in this group are fine grained $(<1 \mathrm{~mm})$ and very intensively foliated. Carbonate grains are elongated mostly in the direction of the shear plane together with subparallel talc scales. Sense of shear can be identified as dextral from rare $\sigma$-type porphyroblasts (Fig. 6b). These mylonitic soapstones have a great number of cleavage domains with different lengths. In some S/C mylonites, the carbonate grains are more randomly orientated or equidimensional but talc occurs as orientated scales composing
C-bands parallel to the shear plane (Fig. 6c). The S/C mylonitic texture was observed in ten specimens (Table 2).

3. Crenulation cleavage (CC) is detected in carbonate soapstones which are very fine grained $(<0.1 \mathrm{~mm})$ in average. Weak crenulation is primarily seen only in talc rich parts and in some samples the texture approaches granoblastic (Fig. 6d). Fig. 6e shows developing crenulation in an early stage. In these samples, carbonate occurs as granular grains and magnetite is commonly euhedral. They differ from S/C mylonites in having a slightly weaker foliation and lack of minor asymmetric structural elements. In addition, the amount of cleavage domains is lower. Crenulation cleavage without mylonitic features was found in eleven specimens (Table 2).

4. Porphyroblastic texture (PB) was recognized in three samples, which are also S/C mylonitic and contain intensively foliated shear bands. Recrystallized carbonate is for a part much coarser than in other specimens (Fig. 6f). The matrix is fine grained $(0.3$ $\mathrm{mm}$ in avg.) and the porphyroblasts are 0.8 to $1.5 \mathrm{~mm}$ in diameter. Carbonate grains and talc scales in the matrix are mainly oriented parallel to the foliation and talc fish structures are orientated along the slip direction of the shear bands.

5. Metamorphic banding (MB) is represented by one specimen consisting of alternating layers of two different mineral compositions, up to $0.5-\mathrm{cm}$-thick carbonate-rich layers and 0.2 -cm-thick talc-magnetite-rich layers (Fig. 6g). Talc shows brownish iron oxide pigmentation and exists as relatively large scales, $0.8 \mathrm{~mm}$ in average (Fig. $6 \mathrm{~h}$ ). They are orientated parallel to the direction of the foliation whereas carbonate in the matrix shows a granular form. 


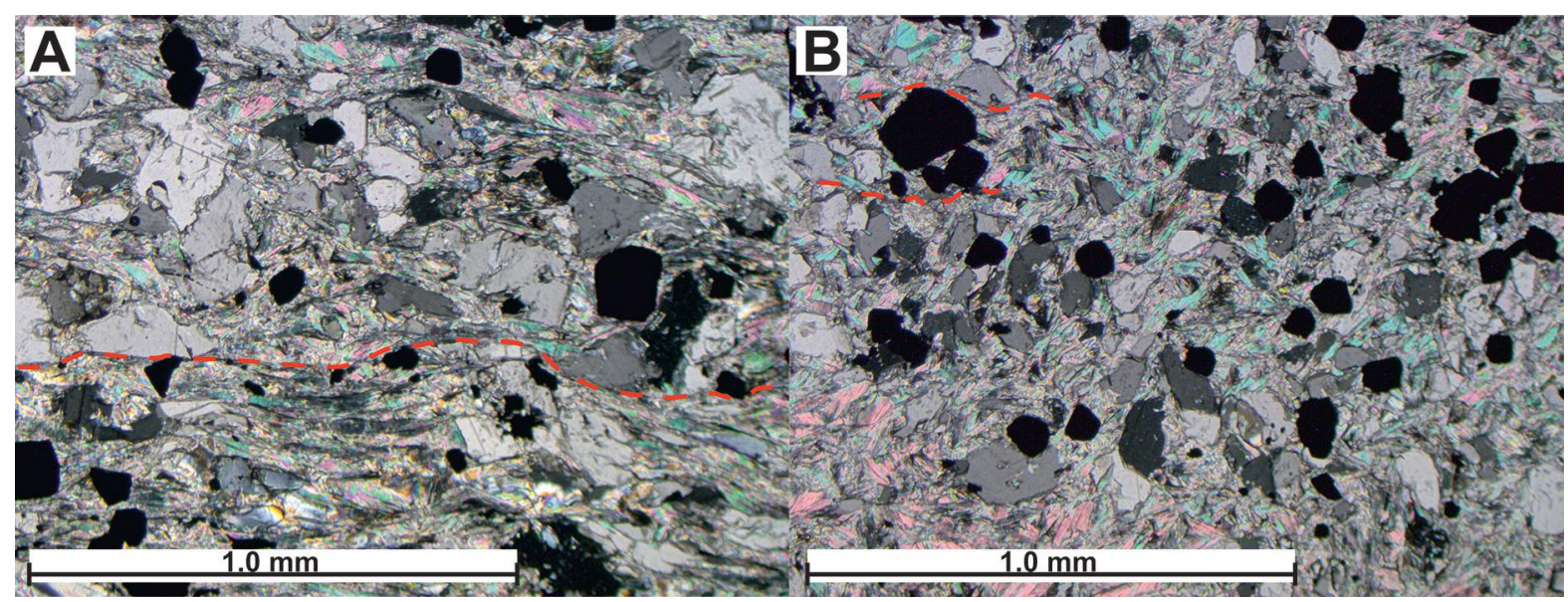

Fig. 5. Examples (dashed lines) of pervasive planar (a), and short rough (b) cleavage domains. Transmitted light, crossed polars.

Table 2. Carbonate soapstone specimens classified by their microtexture.

\begin{tabular}{|c|c|c|c|c|}
\hline Granoblastic & S/C mylonites & Crenulation cleavage & Porphyroblastic & Metamorphic banding \\
\hline \multirow[t]{11}{*}{ MH-03 } & MH-01 & $\mathrm{MH}-02$ & MH-04 & MH-18 \\
\hline & MH-05 & MH-06 & $\mathrm{MH}-15$ & \\
\hline & MH-07 & MH-08 & MH-25 & \\
\hline & MH-10 & MH-09 & & \\
\hline & $\mathrm{MH}-12$ & $\mathrm{MH}-11$ & & \\
\hline & $\mathrm{MH}-13$ & MH-16 & & \\
\hline & MH-14 & $\mathrm{MH}-17$ & & \\
\hline & $\mathrm{MH}-20$ & MH-19 & & \\
\hline & MH-24 & $\mathrm{MH}-21$ & & \\
\hline & MH-26 & $\mathrm{MH}-22$ & & \\
\hline & & MH-23 & & \\
\hline
\end{tabular}

The average grain size distribution of carbonate soapstone specimens is presented in Fig. 7. Every mineral species in polyphasically deformed soapstones has its own characteristic grain size distribution and mode of occurrence. Carbonate displays the largest average grain size $(0.5 \mathrm{~mm})$ with the largest grains being up to $9 \mathrm{~mm}$ in diameter. The talc flakes in every sample are rather small, averaging $0.3 \mathrm{~mm}$, and the average length of elongate chlorite grains remains below $0.2 \mathrm{~mm}$.

\subsection{Correlation of the thermal shock resistance on mineralogical and structural parameters}

Thermal shock resistance experiments were carried out on 26 pieces of carbonate soapstone. The results are shown in Table 3 . The samples are macroscopically gray and seem to be homogeneous, but actually they cover a wide range of structural and mineralogical variations. The thermal 

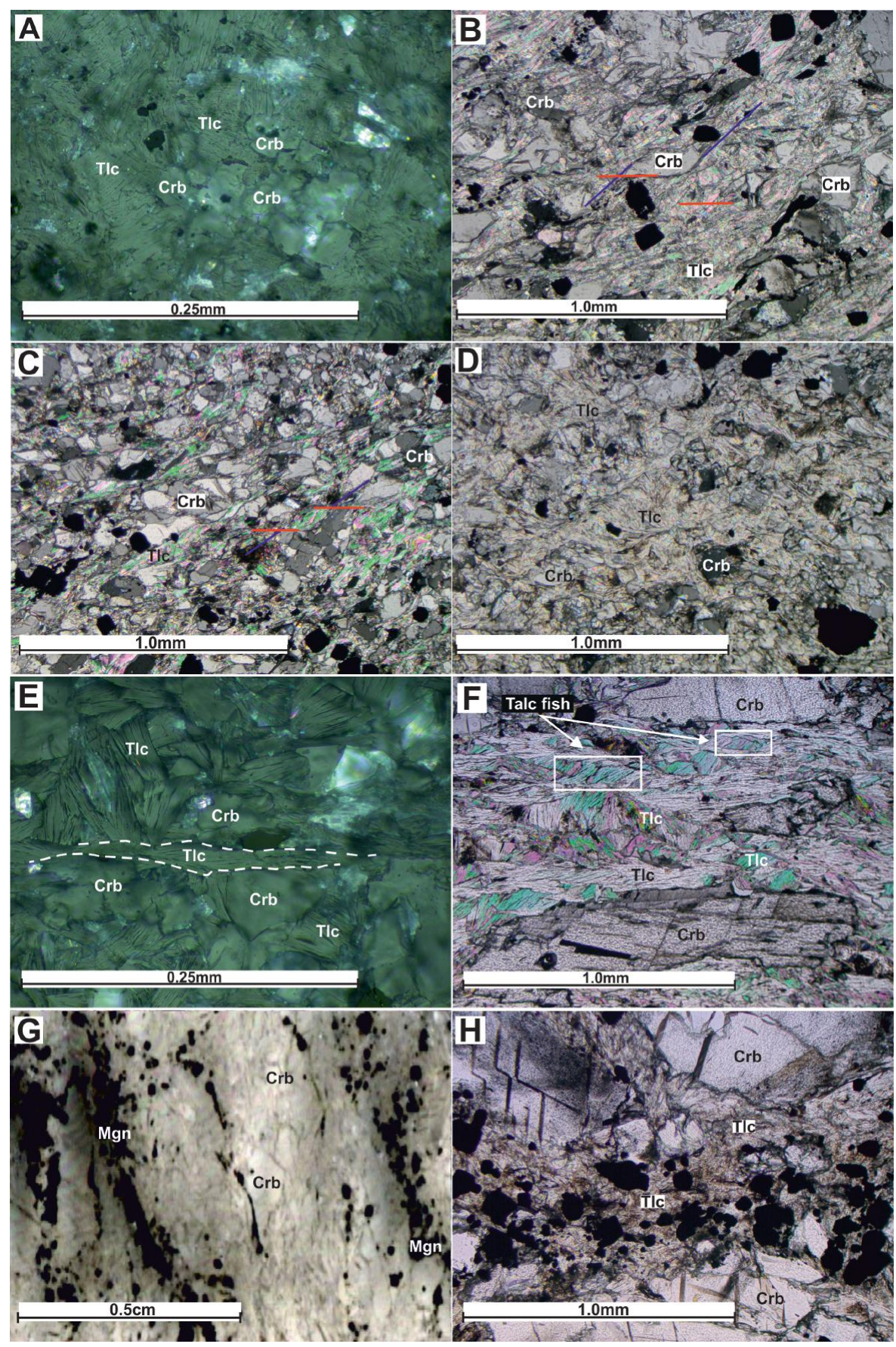

Fig. 6. Photomicrographs of soapstone specimens. a) Very fine-grained granoblastic carbonate soapstone. b and c) C-type shear bands (horizontal, red lines) and S-planes oriented from upper right to lower left corner in S/C-mylonitic carbonate soapstone (blue lines). Dextral shear sense. Volume percentage of cleavage domains is $5 \%$ and the spatial relation between them is conjugate. d) Crenulation cleavage trending from upper right to lower left corner. Percentage of cleavage domains is $2 \%$ at most. Spatial relationship between cleavage domains is parallel. e) An early stage of crenulation cleavage formation (dashed line). f) Porphyroblastic carbonate soapstone with horizontal mylonitic C-type shear band cleavage in the matrix. Talc fish microstructures. Spatial relationship between cleavage domains is conjugate. $\mathbf{g}$ and $\mathbf{h}$ ) Banded carbonate soapstone with alternation of compositional layering of carbonate and talc-magnetite bands. Carbonate (Crb), Magnetite (Mgn), Talc (Tlc). a and e: reflected light, crossed polars; b, c, d, f and h: transmitted light, crossed polars; g: scanned thin section image. 


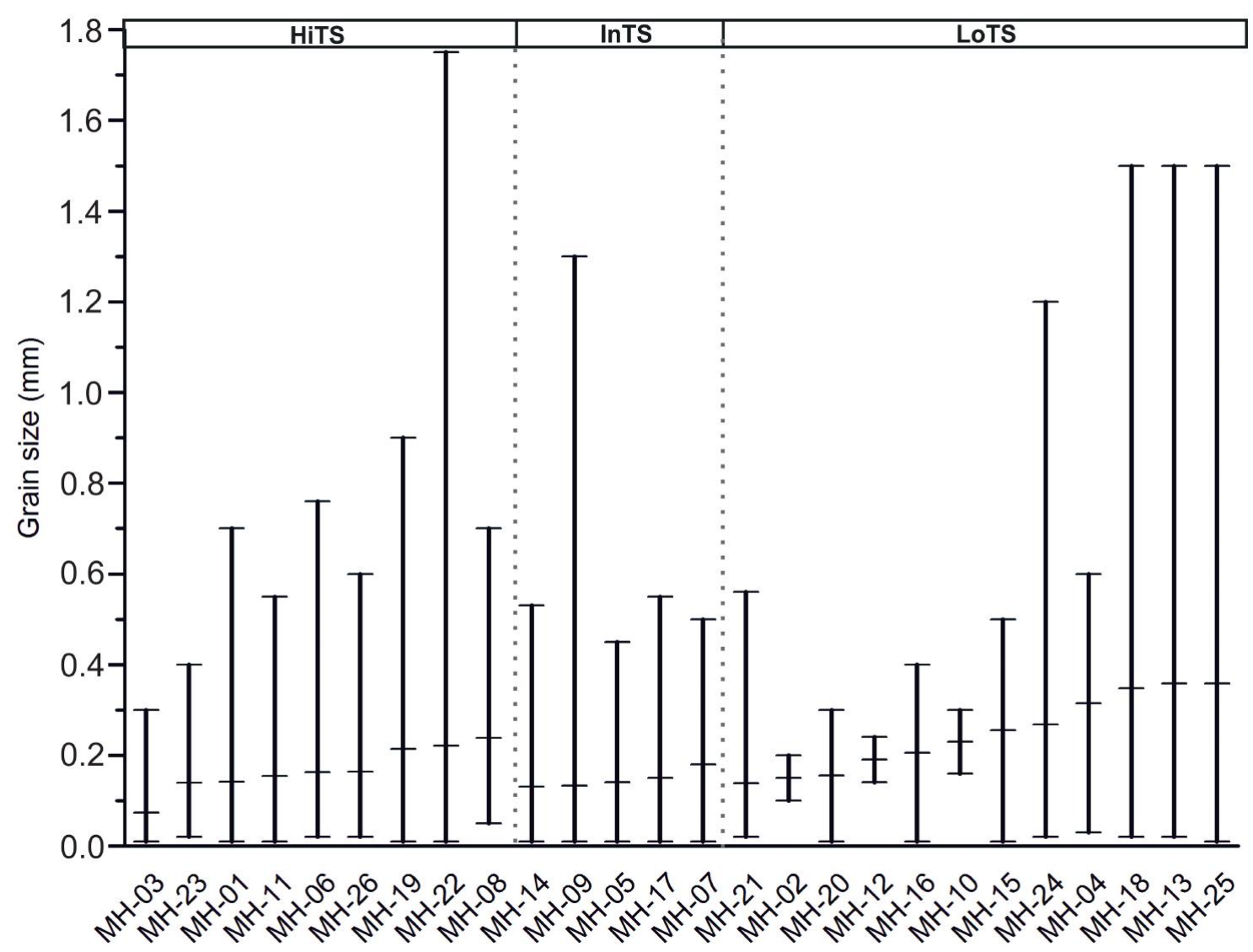

Fig. 7. Average range of mineral grain size for each sample in three thermal shock resistance groups of carbonate soapstone (HiTS =High thermal shock resistance group, InTS =Intermediate thermal shock resistance group, LoTS =Low thermal shock resistance group).

capabilities of these rocks are given as values of thermal shock resistance, which vary from 60 to 95. The carbonate soapstones are divided into three categories on the basis of their resistance of thermal shock: low thermal shock resistance (LoTS, TSR <70), intermediate thermal shock resistance (InTS, TSR between 70 and 80 ), and high thermal shock resistance (HiTS, TSR >80). $46 \%$ (12 pcs) of the studied samples are included in the LoTS group, while $19 \%$ (5 pcs) of them represent the InTS group, and the percentage of the HiTS group is 35 (9 pcs).

\subsubsection{Structural control}

Structural parameters controlling TSR, such as type of foliation, texture and grain size distribution, have been investigated. These attributes affect simultaneously, but with different intensity to thermal properties of the rock.

The average lengths of cleavage domains of the foliation and their average amounts per $1 \mathrm{~cm}^{2}$ were calculated. Also the planarity of cleavage domains was roughly assessed. The calculations and assessments were done under the microscope. The results of these calculations are shown in Table 4. 
Table 3. Results from the thermal shock resistance tests. TSR numbers were determined according to the new method described in this paper. $n=$ number of specimens tested from each sample, TSW (avg.) = average TSW- number, StDev = standard deviation of TSWnumbers of one sample, $\mathrm{T}\left({ }^{\circ} \mathrm{C}\right)=$ testing temperature.

\begin{tabular}{|c|c|c|c|c|c|}
\hline Sample & TSR-number & $\mathrm{T}\left({ }^{\circ} \mathrm{C}\right)$ & TSW (avg.) & StDev & $\mathbf{n}$ \\
\hline MH-03 & 95 & 950 & 23 & 2.7 & 5 \\
\hline MH-01 & 89 & 1000 & 6.4 & 1.82 & 5 \\
\hline MH-06 & 90 & 900 & 26 & 1.14 & 5 \\
\hline MH-08 & 91 & 900 & 30 & 0 & 6 \\
\hline MH-11 & 92 & 950 & 19.4 & 2.97 & 5 \\
\hline MH-19 & 89 & 900 & 29 & 0 & 5 \\
\hline MH-22 & 87 & 900 & 23 & 2.64 & 6 \\
\hline $\mathrm{MH}-23$ & 91 & 950 & 15.5 & 1.76 & 6 \\
\hline MH-26 & 93 & 1000 & 9.8 & 0.84 & 5 \\
\hline MH-07 & 77 & 900 & 4.4 & 0.55 & 5 \\
\hline MH-09 & 77 & 900 & 4.4 & 1.52 & 5 \\
\hline MH-17 & 78 & 900 & 5 & 2.12 & 5 \\
\hline MH-05 & 73 & 900 & 2.8 & 1.1 & 5 \\
\hline MH-14 & 73 & 900 & 2.4 & 0.55 & 5 \\
\hline $\mathrm{MH}-02$ & 65 & 750 & 7 & 0 & 5 \\
\hline $\mathrm{MH}-04$ & 67 & 800 & 4.2 & 0.45 & 5 \\
\hline $\mathrm{MH}-10$ & 64 & 700 & 11.6 & 2.19 & 5 \\
\hline $\mathrm{MH}-12$ & 63 & 700 & 9.8 & 1.1 & 5 \\
\hline $\mathrm{MH}-13$ & 65 & 800 & 3.6 & 0.89 & 5 \\
\hline $\mathrm{MH}-21$ & 68 & 900 & 2.5 & 1.38 & 6 \\
\hline $\mathrm{MH}-20$ & 67 & 800 & 4.5 & 2.43 & 6 \\
\hline $\mathrm{MH}-18$ & 63 & 700 & 10 & 0 & 5 \\
\hline $\mathrm{MH}-16$ & 62 & 700 & 9.2 & 1.48 & 5 \\
\hline $\mathrm{MH}-15$ & 61 & 800 & 1.6 & 0.89 & 5 \\
\hline $\mathrm{MH}-24$ & 63 & 800 & 2.3 & 0.52 & 6 \\
\hline MH-25 & 60 & 700 & 6.6 & 2.25 & 6 \\
\hline
\end{tabular}

The average length of the cleavage domains is 1.3 $\mathrm{mm}$ in the HiTS group. For the InTS and LoTS groups, the value is 1.9 and $3.2 \mathrm{~mm}$, respectively. It needs to be noted that the calculation was only based on five samples in the LoTS group, because the cleavage domains are pervasive and thereby not measurable from the thin sections in the rest of the seven cases. The average frequency of cleavage domains is $65.8 \mathrm{pcs} / \mathrm{cm}^{2}$ in the HiTS group, 62.3 $\mathrm{pcs} / \mathrm{cm}^{2}$ in the InTS group, and $48.8 \mathrm{pcs} / \mathrm{cm}^{2}$ in the LoTS group. The majority (7/9) of the carbonate soapstones show a rough planarity of cleavage domains in the HiTS group. Respectively, 2/5 of the samples in the InTS group and 3/12 in the LoTS group have cleavage domains that show a rough planarity. 
Table 4. Average lengths and frequencies of cleavage domains of carbonate soapstone samples. The appearance of the cleavage domains has been classified as flat or rough. $\mathrm{P}=$ Pervasive (cleavage domain continues over the edges of thin section, $>2,5 \mathrm{~cm}$ )

\begin{tabular}{|c|c|c|c|c|}
\hline Sample & TSR-group & Average Length (mm) & $\mathrm{PCS} / 1 \mathrm{~cm}^{2}$ & Planarity \\
\hline MH-03 & HiTS & 0.4 & 19.05 & Rough \\
\hline MH-01 & HiTS & 1.8 & 46.3 & Flat \\
\hline MH-06 & HiTS & 1.5 & 42.09 & Rough \\
\hline MH-08 & HiTS & 2 & 67.34 & Rough \\
\hline $\mathrm{MH}-11$ & HiTS & 1 & 29.46 & Rough \\
\hline MH-19 & HiTS & 0.8 & 84.18 & Rough \\
\hline MH-22 & HiTS & 1.5 & 101.02 & Rough \\
\hline $\mathrm{MH}-23$ & HiTS & 1 & 50.51 & Rough \\
\hline MH-26 & HiTS & 1 & 105.23 & Flat \\
\hline MH-07 & InTS & 0.8 & 122.06 & Rough \\
\hline MH-09 & InTS & 2 & 16.84 & Flat \\
\hline MH-17 & InTS & 2.2 & 29.46 & Flat \\
\hline MH-05 & InTS & 1.5 & 75.76 & Rough \\
\hline $\mathrm{MH}-14$ & InTS & 3.4 & 67.34 & Flat \\
\hline $\mathrm{MH}-02$ & LoTS & 3 & 33.67 & Rough \\
\hline $\mathrm{MH}-04$ & LoTS & $P$ & 12.63 & Rough \\
\hline $\mathrm{MH}-10$ & LoTS & $P$ & 46.3 & Flat \\
\hline $\mathrm{MH}-12$ & LoTS & 3.8 & 67.34 & Flat \\
\hline $\mathrm{MH}-13$ & LoTS & $P$ & 50.51 & Flat \\
\hline MH-21 & LoTS & 3.7 & 33.67 & Rough \\
\hline $\mathrm{MH}-20$ & LoTS & $P$ & 101.02 & Flat \\
\hline $\mathrm{MH}-18$ & LoTS & 3 & 25.25 & Flat \\
\hline MH-16 & LoTS & $P$ & 37.88 & Flat \\
\hline MH-15 & LoTS & $\mathrm{P}$ & 21.05 & Flat \\
\hline $\mathrm{MH}-24$ & LoTS & $P$ & 29.46 & Flat \\
\hline MH-25 & LoTS & 2.7 & 126.27 & Flat \\
\hline
\end{tabular}

The rocks can be divided into four categories on the basis of the measured lengths of cleavage domains. The cleavage domains with a length of $<1.0 \mathrm{~mm}$ are regarded as short, from $>1.0 \mathrm{~mm}$ to $\leq 2.0 \mathrm{~mm}$ as low intermediate, from $>2.0 \mathrm{~mm}$ to $\leq 4 \mathrm{~mm}$ as intermediate, and $>2.5 \mathrm{~cm}$ as pervasive. The class between $4 \mathrm{~mm}$ to $2,5 \mathrm{~cm}$ is non-existing, because all cleavage domains with the length over 4 $\mathrm{mm}$ are pervasive in the scale of thin sections. Fewer than 60 cleavage domains per $\mathrm{cm}^{2}$ are considered as a low occurrence and $>60 \mathrm{pcs} / \mathrm{cm}^{2}$ as a high occurrence. The frequency and length of cleavage domains amongst the TSR and microtexture groups are presented in Table 5. The numbers of the four cleavage domain groups are indicators of their actual length. Therefore, the average values of cleavage domain length categories considered with the TSR number and microtexture distributions are directly comparable with the genuine measurements. Taking this into account, as the table 5 shows, the 


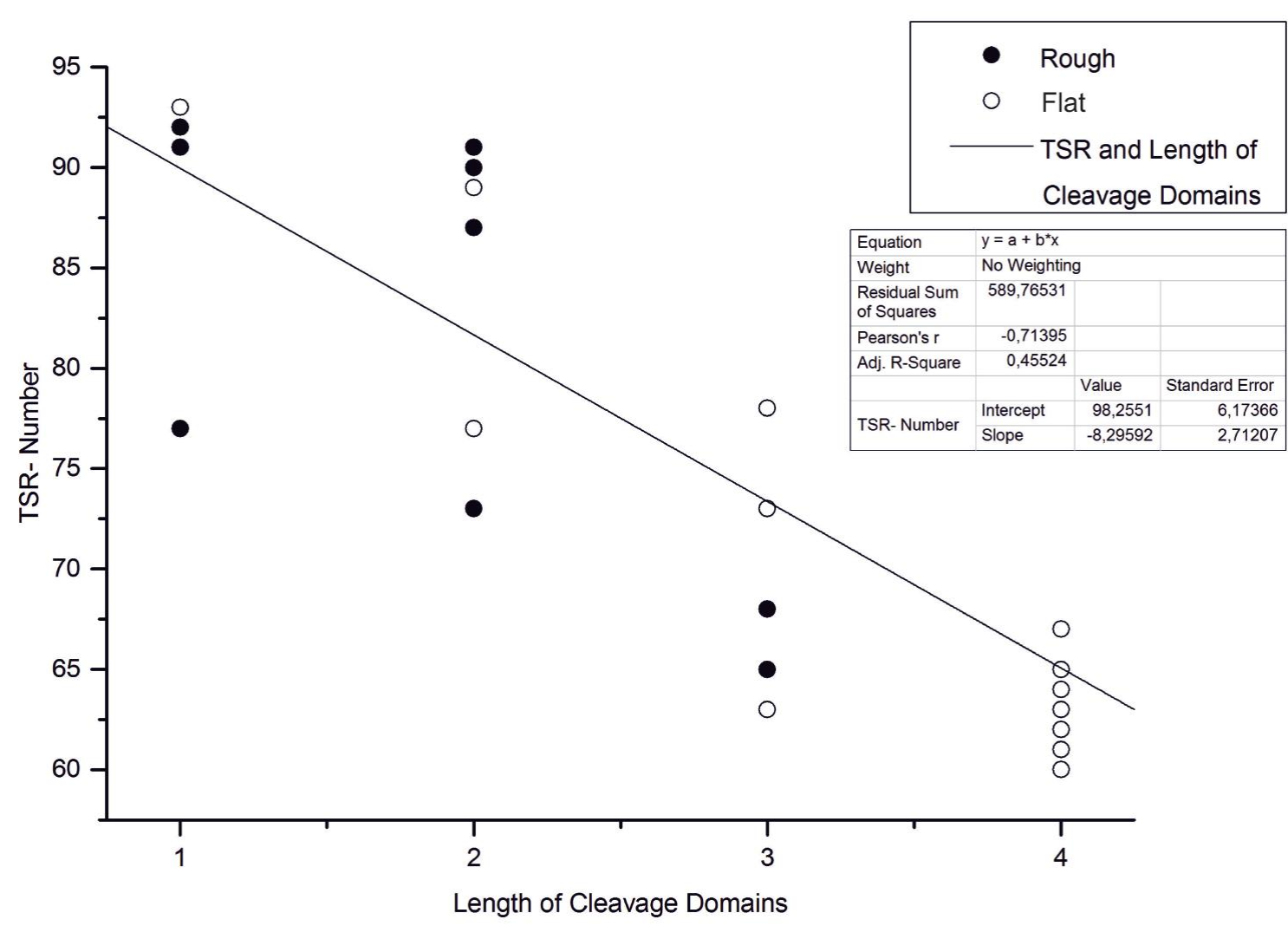

Fig. 8. Average length of cleavage domains plotted against TSR in carbonate soapstones. Black dots represent rough and hollow dots flat planarity of cleavage domains. Length classes: $1=\leq 1 \mathrm{~mm}, 2=$ from $>1 \mathrm{~mm}$ to $\leq 2 \mathrm{~mm}, 3=$ from $>2 \mathrm{~mm}$ to $\leq 4.0 \mathrm{~mm}, 4=>2.5 \mathrm{~cm} .4$ referred to as pervasive in the text.

average CD length values in the HiTS group with a $\mathrm{S} / \mathrm{C}$ mylonitic texture and with crenulation cleavage are both 1.5. Respectively, in the InTS group, the average $\mathrm{CD}$ value of S/C mylonites is 2.0 and the value for crenulation cleavage is 2.5 . In the case of the LoTS group, the average CD values are 3.8 for samples with a S/C mylonitic texture, 3.3 with a crenulation cleavage, 4.0 with a porphyroblastic texture, and 3.0 with metamorphic banding. Figure 8 shows the correlation between the thermal shock resistivity and length of cleavage domains in carbonate soapstones.

Figure 9 illustrates the relationship between the textural type and thermal shock resistance of carbonate soapstone samples. The greatest differences between HiTS, InTS and LoTS are in the presence of very fine-grained cleavage, which only occurs in HiTS, and in porphyroblastic, as well as metamorphic banded textures which appear exclusively in LoTS. Textures of S/C mylonite and crenulation cleavage are present in samples displaying the whole range of thermal shock resistance.

Average grain sizes of carbonate soapstones are presented in Fig. 7 These range from 0.07 to 0.35 $\mathrm{mm}$. Carbonate soapstones of the HiTS group are very fine grained to fine grained. The TSR group contains fine-grained soapstones on average. The largest grain size is observed in the LoTS group and the soapstone samples of this group have the largest difference between the maximum and minimum grain sizes. Groups of HiTS, InTS and LoTS are also distinguished in Fig. 10 where the grain size is plotted against TSR number. Expectedly, the grain size correlates with the thermal shock resistance. Figure 10 shows negative correlation between TSR and the average grain size in HiTS and LoTS groups. It also indicates that the soapstone samples with a porphyroblastic texture or metamorphic banding have the coarsest grain size and lowest capacity to resist thermal shock. 
Table 5. Frequency and length of cleavage domains amongst TSR groups and microtexture categories in carbonate soapstone samples. $\mathrm{CD}=$ The length of cleavage domains, $1=<1 \mathrm{~mm}, 2=>1 \mathrm{~mm}$ to $\leq 2 \mathrm{~mm}, 3>2 \mathrm{~mm} \leq 4.0 \mathrm{~mm}, 4=>2$, $5 \mathrm{~cm} . \mathrm{f}=$ Frequency, Low $=<60 \mathrm{pcs} / \mathrm{cm} 2, \mathrm{High}=>60 \mathrm{pcs} / \mathrm{cm} 2$.

\begin{tabular}{|c|c|c|c|c|c|c|c|c|c|c|}
\hline \multirow[b]{2}{*}{ TSR } & \multicolumn{2}{|c|}{ Granoblastic } & \multicolumn{2}{|c|}{ S/C mylonite } & \multicolumn{2}{|c|}{ Crenulation cleavage } & \multicolumn{2}{|c|}{ Porphyroblastic } & \multicolumn{2}{|c|}{ Metamorphic banding } \\
\hline & CD & $f$ & $C D$ & $f$ & CD & $f$ & CD & $\mathbf{f}$ & CD & $\mathbf{f}$ \\
\hline \multirow[t]{6}{*}{ HITS } & 1 & Low & 1 & High & 1 & Low & & & & \\
\hline & & & 2 & Low & 1 & Low & & & & \\
\hline & & & & & 2 & High & & & & \\
\hline & & & & & 2 & High & & & & \\
\hline & & & & & 2 & Low & & & & \\
\hline & & & & & 1 & High & & & & \\
\hline \multirow[t]{3}{*}{ InTS } & & & 2 & High & 3 & Low & & & & \\
\hline & & & 1 & High & 2 & Low & & & & \\
\hline & & & 3 & High & & & & & & \\
\hline \multirow[t]{5}{*}{ LoTS } & & & 4 & High & 3 & Low & 4 & Low & 3 & Low \\
\hline & & & 3 & High & 4 & Low & 4 & Low & & \\
\hline & & & 4 & Low & 3 & Low & 4 & High & & \\
\hline & & & 4 & Low & & & & & & \\
\hline & & & 4 & Low & & & & & & \\
\hline
\end{tabular}

\subsubsection{Mineralogical control}

The chemical composition of each individual mineral species has an effect on the physical properties of the rock. Chemical compositions of the main minerals were analyzed by microprobe. The HiTS, InTS and LoTS groups also appear in Fig. 11, where cationic $\mathrm{Fe} /(\mathrm{Mg}+\mathrm{Fe})$ ratio in talc is presented with TSR of carbonate soapstones.

Carbonates in carbonate soapstones are magnesite varieties with different amounts of siderite and calcite components. Their $\mathrm{FeO}$ content falls in the range of 2.9-12.1 wt $\%$ and they contain only small amounts of manganese and other trace elements. Therefore, carbonates were projected on the generally used magnesite-siderite-calcite ternary diagram (Fig. 12a). Variation of the siderite component is also observed in different parts of individual magnesite grains. Molar $\mathrm{Fe} /(\mathrm{Mg}+\mathrm{Fe})$ ratios in magnesite grains are presented in Fig. $12 \mathrm{~b}$, with the compositions being divided into three separate groups. The $\mathrm{Fe} /(\mathrm{Mg}+\mathrm{Fe})$ ratio of magnesite does not exceed 0.16 in any of the TSR groups.

A small amount of chlorite was found in some carbonate soapstone variants. The percentage of chlorite is $5 \%$ in maximum and it does not have significant effect to TSR. The chemical composition of chlorite is clearly the most versatile. The physical properties of the chlorite group minerals vary widely due to the diadochic substitution, with the iron content being one of the major variables. The analyzed chlorite grains show $\mathrm{FeO}$ contents from 2.5 to $7.7 \mathrm{wt} \%$ and they can be classified as clinochlore, penninite, or talc-chlorite depending on the total amount of silicon and iron (Fig. 13). Figure 14 shows that large variations in mineral compositions are found in all three TSR groups (LoTS, InTS and HiTS) defined by thermal shock resistance experiments. Thus it appears that the mineralogical composition does not correlate with the TSR classification. 


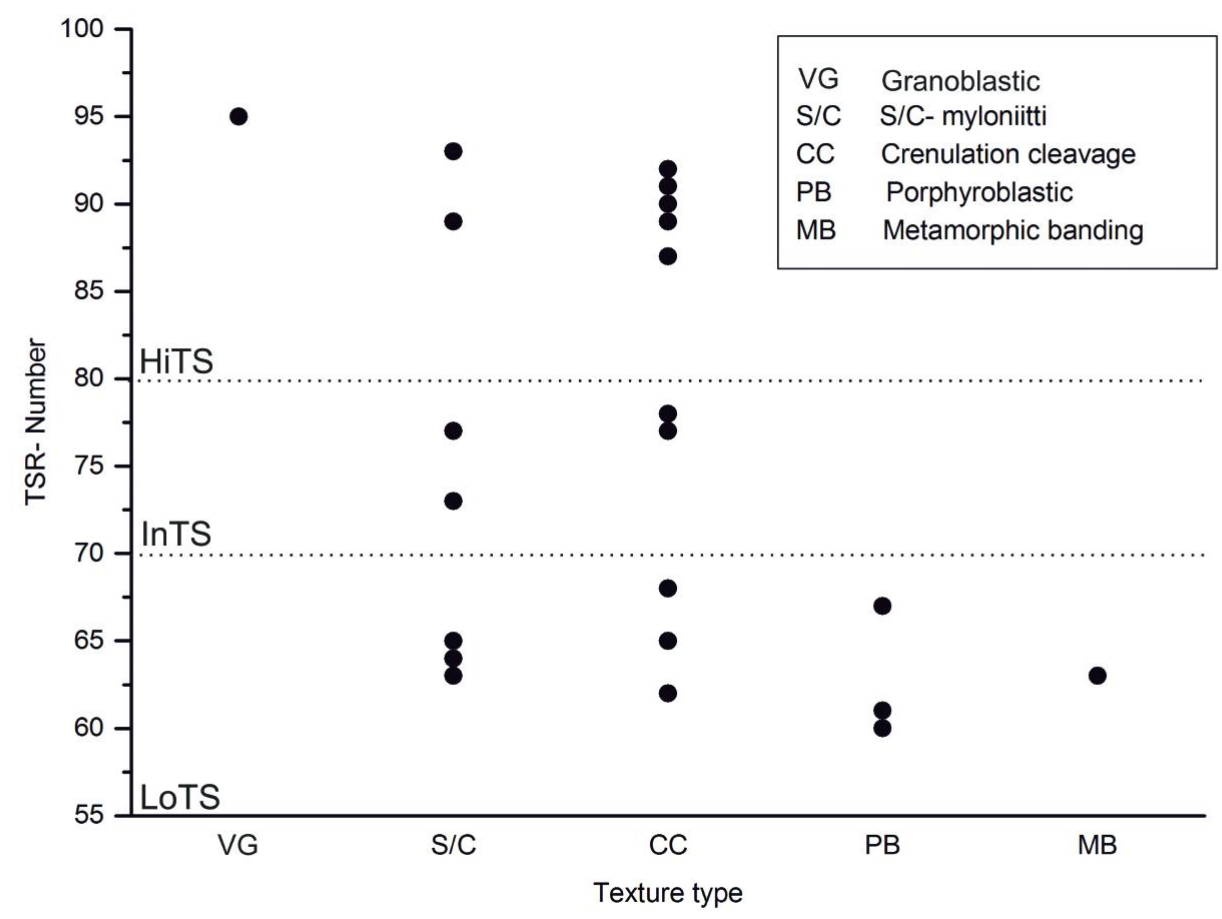

Fig. 9. Relationship between TSR numbers (Table 3) and different textural types of carbonate soapstone. Samples with S/C-mylonitic and crenulation cleavage textures are divided into three groups with high, intermediate and low TSR values

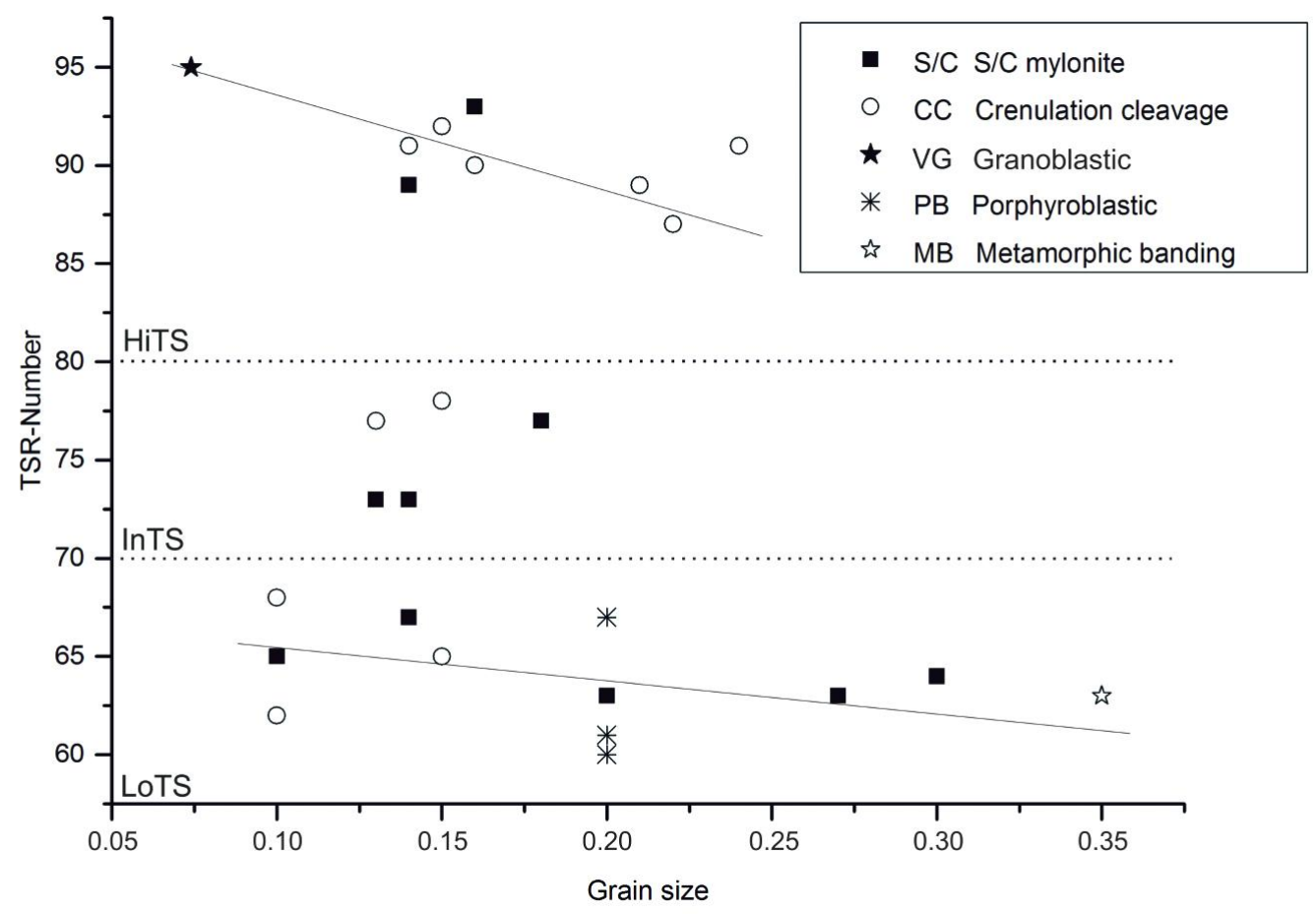

Fig. 10. Average grain size against TSR for carbonate soapstones with different microtextures and TSR groups. 


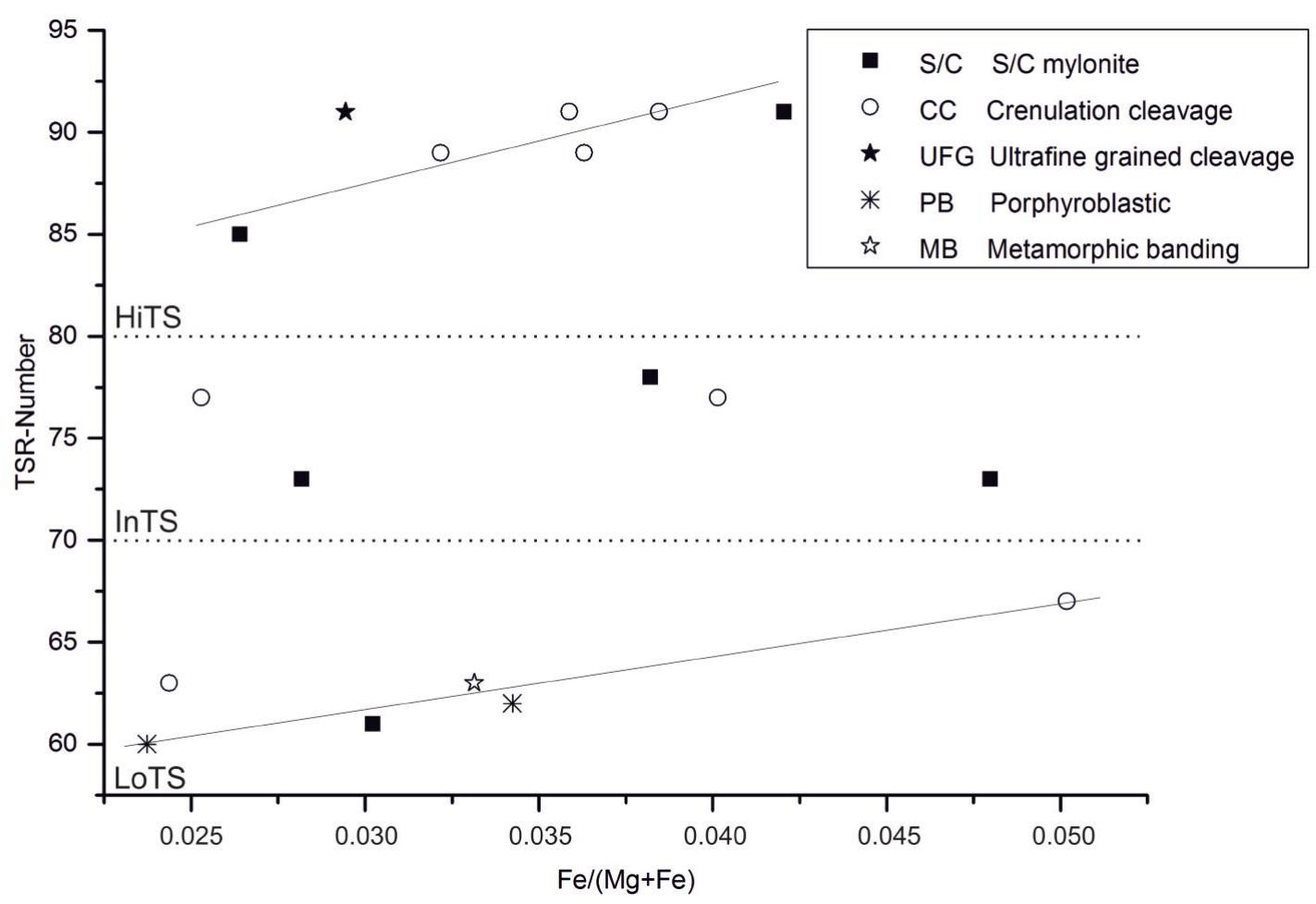

Fig. 11. Fe/(Mg+Fe) ratios in talc vs. thermal shock resistance of carbonate soapstones with different microtextures and TSR groups.

Microtextural studies by the electron microprobe indicated that magnesite is the only mineral in which the internal microtexture of individual mineral grains shows a significant variation. Magnesite often occurs as polycrystalline grains. The grains are either homogeneous or zoned due to the variation in the iron content; a lighter tone in back-scattered images indicates a more iron-rich composition (Fig. 15). Some magnesite grains are more strongly zoned than others, and in some cases, the inner part of the grain is iron rich whereas the outer parts are iron poor, and conversely. The goal was to assess whether the chemical composition of magnesite has any effect on the thermal shock resistance of carbonate soapstones. No correlation was found between the distribution of compositional zoning in magnesite grains and the thermal shock resistance of carbonate soapstones.

In general, mineral composition has a significant effect to the thermal properties of the rock, but the compositional spread of the studied specimens is very limited and therefore it does not play an essential role in the variation of the TSR numbers.

\section{Discussion}

\subsection{Length and frequency of cleavage domains controlling TSR}

Mechanically weak discontinuities can result from foliation. However, the microcrenulation observed in the studied carbonate soapstones may create pervasive microfolding into the previously foliated rocks. This crenulation may increase the strength of the rock by interfering the phase boundaries and similarly orientated structural elements. 


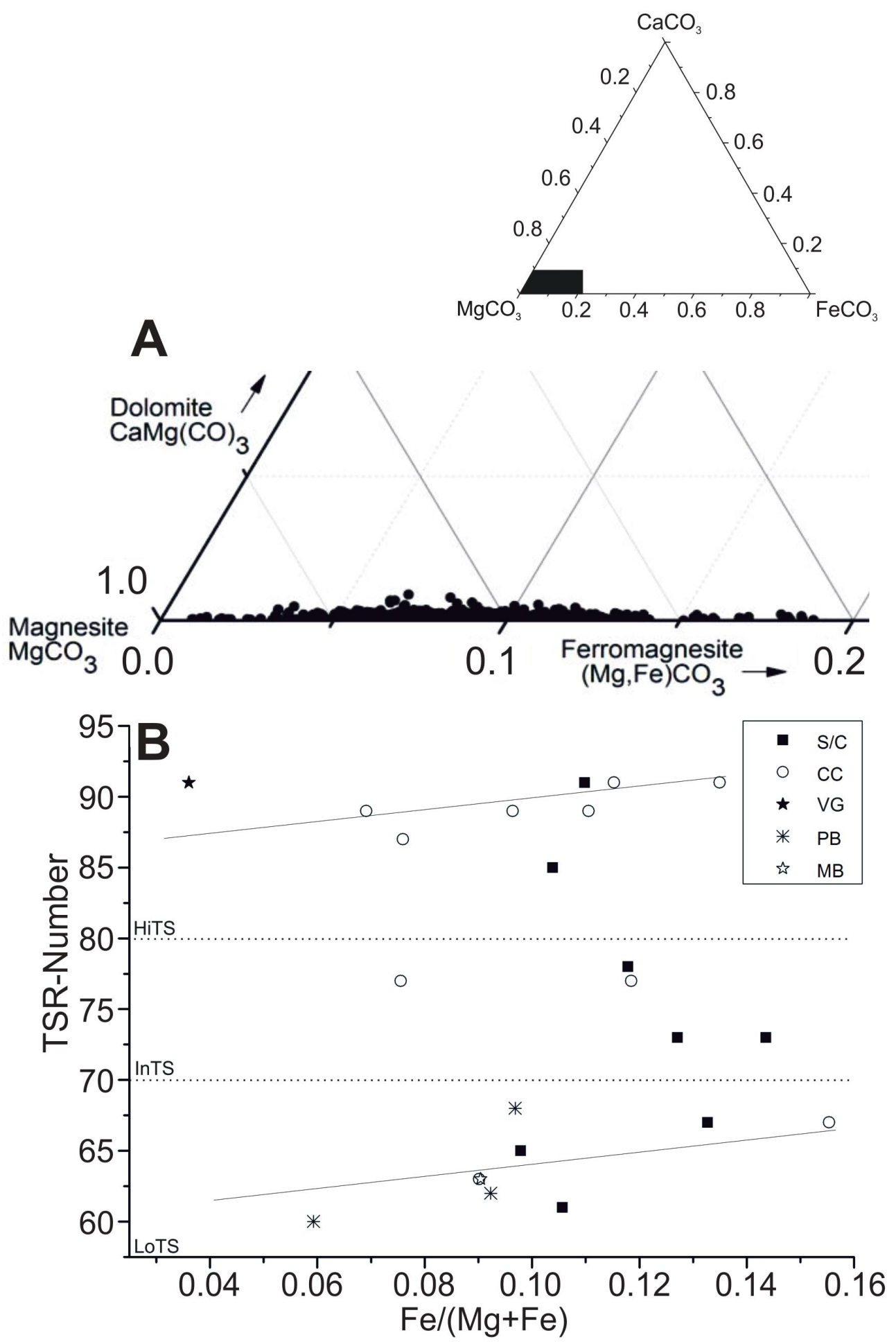

Fig. 12. a) Left lower corner of the ternary $\mathrm{MgCO}_{3}-\mathrm{FeCO}_{3}-\mathrm{CaCO}_{3}$ diagram showing carbonate mineral compositions in carbonate soapstones. b) $\mathrm{Fe} /(\mathrm{Mg}+\mathrm{Fe})$ ratios in magnesite vs. thermal shock resistance of carbonate soapstone with different microtextures. The TSR- results show groups of HiTS (High thermal shock resistance group), InTS (Intermediate thermal shock resistance group), and LoTS (Low thermal shock resistance group) 


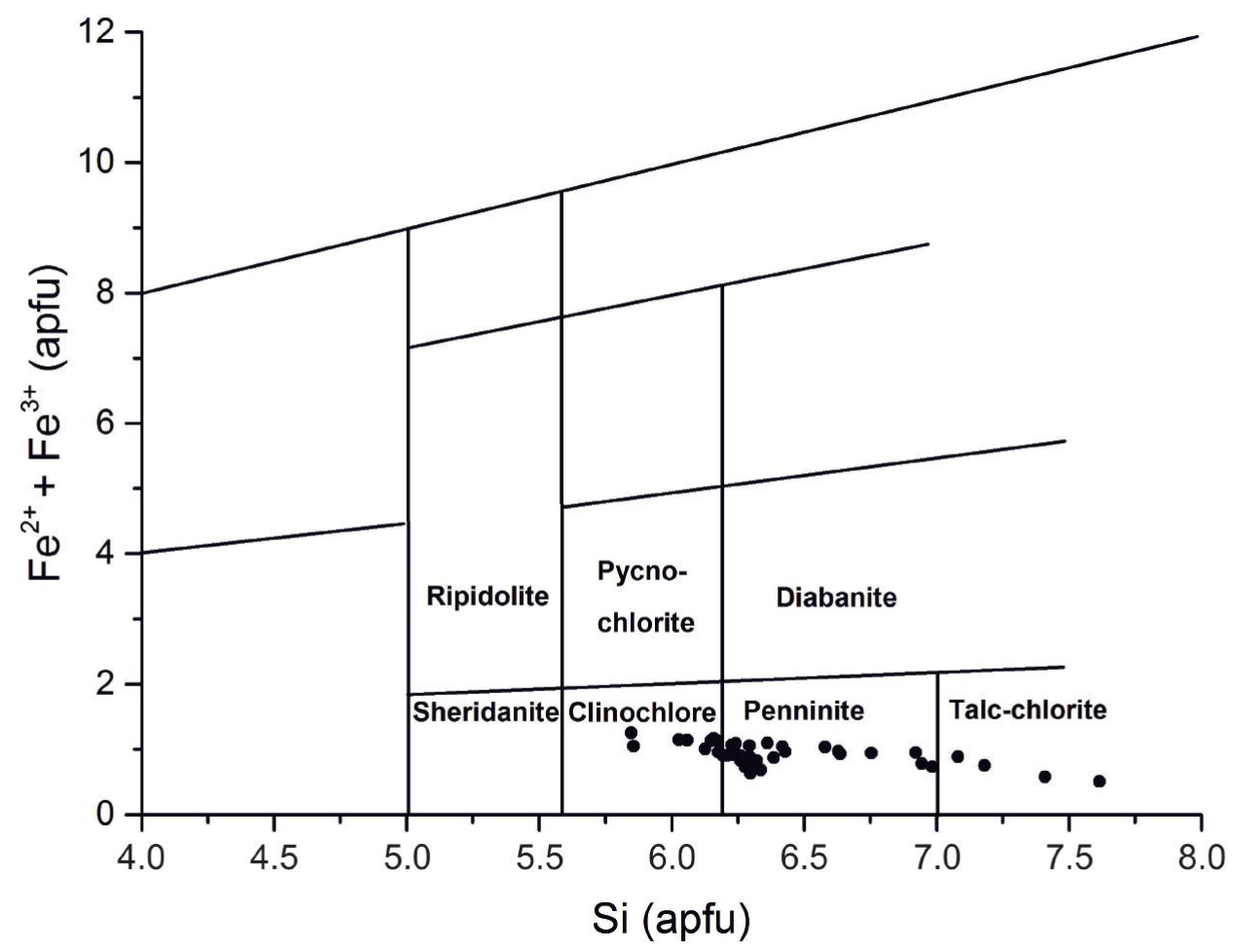

Fig. 13. Chlorite compositions plotted on the classification of chlorite minerals of Hey (1954). The compositions were calculated on the basis of 28 oxygens and with $\mathrm{Fe}^{2+} / \mathrm{Fe}^{3+}$ and $\mathrm{OH}$ assuming full site occupancy.

Regarding the latest foliation, the observations of the length, frequency and planarity of cleavage domains in the investigated carbonate soapstones reveal that the character of cleavage domains has an utmost importance to the thermal shock resistance. Especially the length of cleavage domains has a significant effect on TSR. Table 5 shows that the shorter the average cleavage domains are, the higher the TSR numbers are. Figure 16 demonstrates that the grain size distribution and TSR show a negative correlation within all length classes of cleavage domains. The frequency of cleavage domains only plays a minor role in determining the thermal shock resistance. Frequently occurring cleavage domains and their pervasive length produced the lowest TSR. As indicated by Fig. 8, there is a strong negative correlation between the length of cleavage domains and TSR test results. In addition, the rough planarity of cleavage domains correlates with higher thermal shock resistance, whereas the flat form of planarity is related to lower TSR. Apparently, a flat planarity of cleavage domains allows heat to conduct more freely in the direction of the plane.

\subsection{Textural type controlling TSR}

The textural type of carbonate soapstone has a significant effect on the thermal shock resistance. For example, Fig. 9 indicates that the presence of metamorphic banding and porphyroblasts have a negative influence on TSR. Coherent boundary surfaces are characteristic for these types of textures and occur as layer boundaries of different composition or as grain boundaries of large porphyroblasts. 
The strength of grain boundaries increases with the increasing complexity in the grain shape. This can be due to decussate or sutured grain boundaries or the presence of sub-grains at the grain boundaries (Lindquist et al., 2007). The pervasive microcrenulated folding in S/C mylonitic and crenulation cleavage textures was observed to have a similar influence. Increasing disorder in the grain boundary geometry enhances the resistance to thermal wear (Howarth, 1986). Also, the resistance to mechanical fragmentation is reflected by these parameters (Åkesson et al., 2003).

\subsection{Grain size controlling TSR}

In general, isotropic and fine-grained soapstones are more resistant to rapid temperature changes than more heterogeneous and coarse-grained soapstones. If the specimen has a low TSR despite of its finegrained texture and suitable mineral composition, the type of texture has a crucial role in resisting thermal shock.

Figure 7 shows that the HiTS group includes only a small number of samples with the maximum grain size of $>1 \mathrm{~mm}$. Examination of the relationship between the grain size and thermal shock resistance and microtextures reveals that the TSR in the S/C mylonite group is compatible with expectations: smaller grain sizes produced higher TSR values. The situation in the crenulation cleavage group was opposite: larger average grain sizes produced higher TSR values (Table 6, Fig. 10). In their study of microstructures and functional properties of rock materials, Lindquist et al. (2007) also pointed out the importance of the grain size distribution along with the grain size itself. They observed that a wide grain size range produced more durable and higher resistance to fragmentation and wear. Our studies show that the higher the average standard deviations of grain sizes are, the lower the TSR values are (Table 6). This negative correlation between the variability of grain size and thermal shock resistance is illustrated in Fig. 16. However, the obtained data have to be interpreted with care because other textural forms also have an influence on the results.
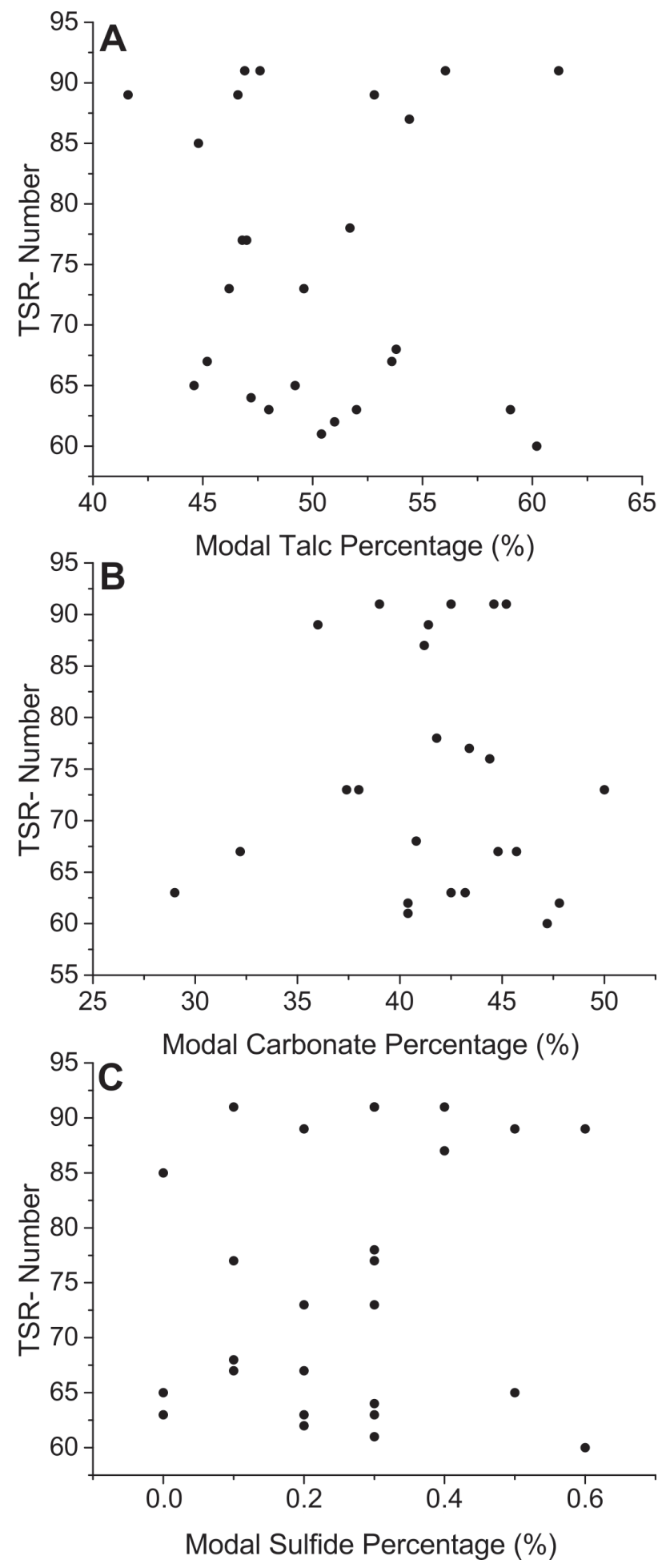

Fig. 14. a) Variation of thermal shock resistance of carbonate soapstone samples vs. modal percentage of talc (a), carbonate (b) and sulfide (c). 


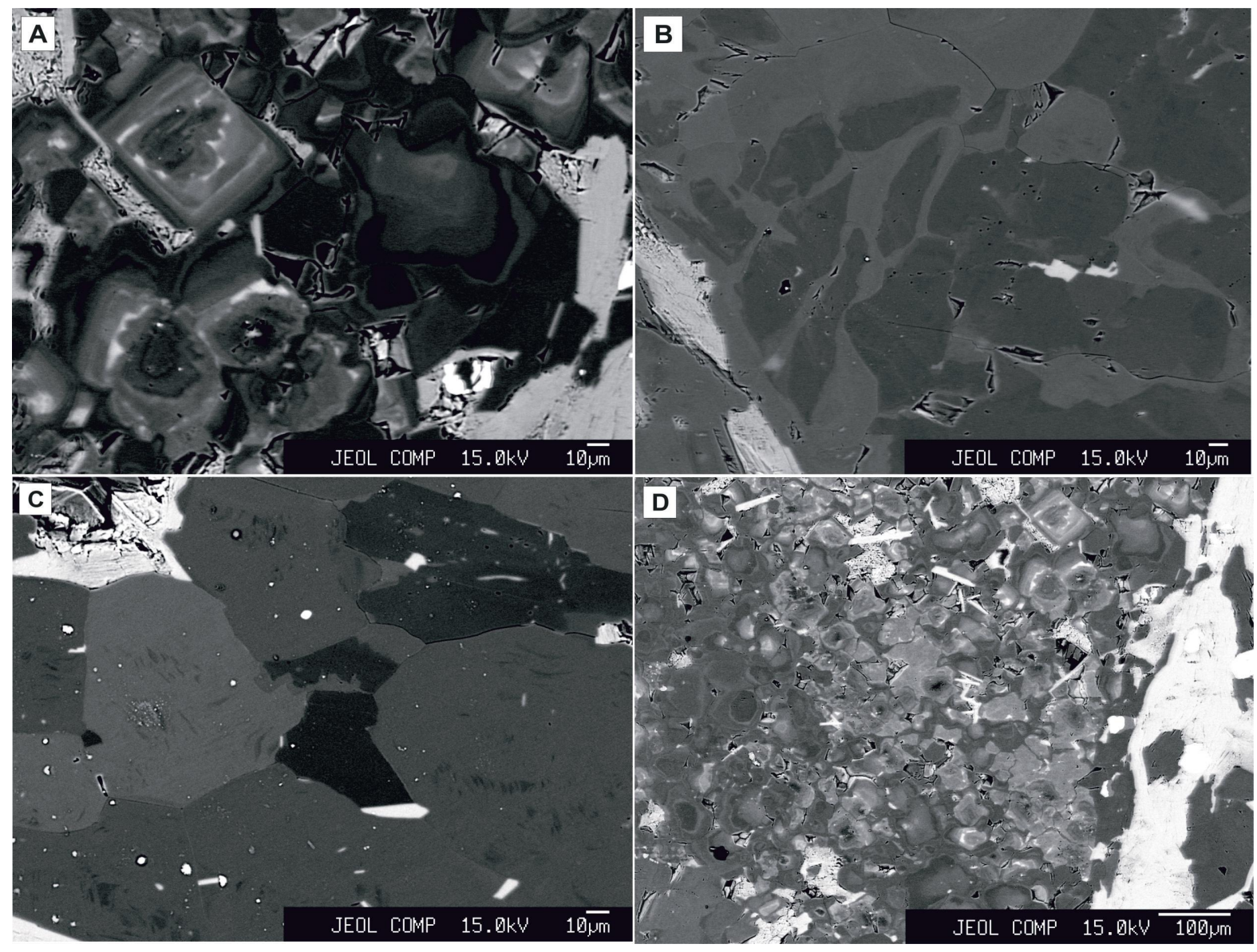

Fig. 15. Back-scattered electron images of soapstone samples with polycrystalline magnesite grains. Magnesite can be chemically homogeneous (c) or zoned with iron-enriched inner parts (a and d) or iron-poor inner parts (b).

\subsection{Mineralogical composition controlling TSR}

The carbonate soapstone samples selected to this study represent a limited range of chemical composition. The $\mathrm{Fe} /(\mathrm{Mg}+\mathrm{Fe})$ ratio in talc shows a moderate variation and, as indicated by Fig. 11, has only a minor effect on TSR. There is a slight positive correlation between the iron content of talc and TSR in the HiTS and LoTS groups. Three TSR groups occur in Fig. 11. Analogously with the iron content of talc, increasing of $\mathrm{Fe} /(\mathrm{Mg}+\mathrm{Fe})$ in magnesite slightly enhances TSR within the HiTS and LoTS groups (Fig. 12b). A dolomitic composition has a decreasing effect on the thermal shock resistance of soapstone, due to the reactivity of $\mathrm{CaO}$ with the water medium used in the TSR tests. However, the carbonate grains analyzed in this study are magnesite containing a minor or nonexistent calcite component (Fig. 12a). Thus, as Fig. 17 shows, the percentage of $\mathrm{CaO}$ does not have any effect on TSR. This applies also to chlorite; because of the minor abundances (see Table 1) in the investigated samples, composition of chlorite does not influence on thermal shock resistance of soapstones in any TSR groups.

Although talc occurs in all soapstone types, its quantity does not have a substantial role in the capacity of soapstones to resist thermal shock. Figures $14 \mathrm{a}$ and $14 \mathrm{~b}$ show that there is no correlation between the talc and carbonate percentages and thermal shock resistivity. The 


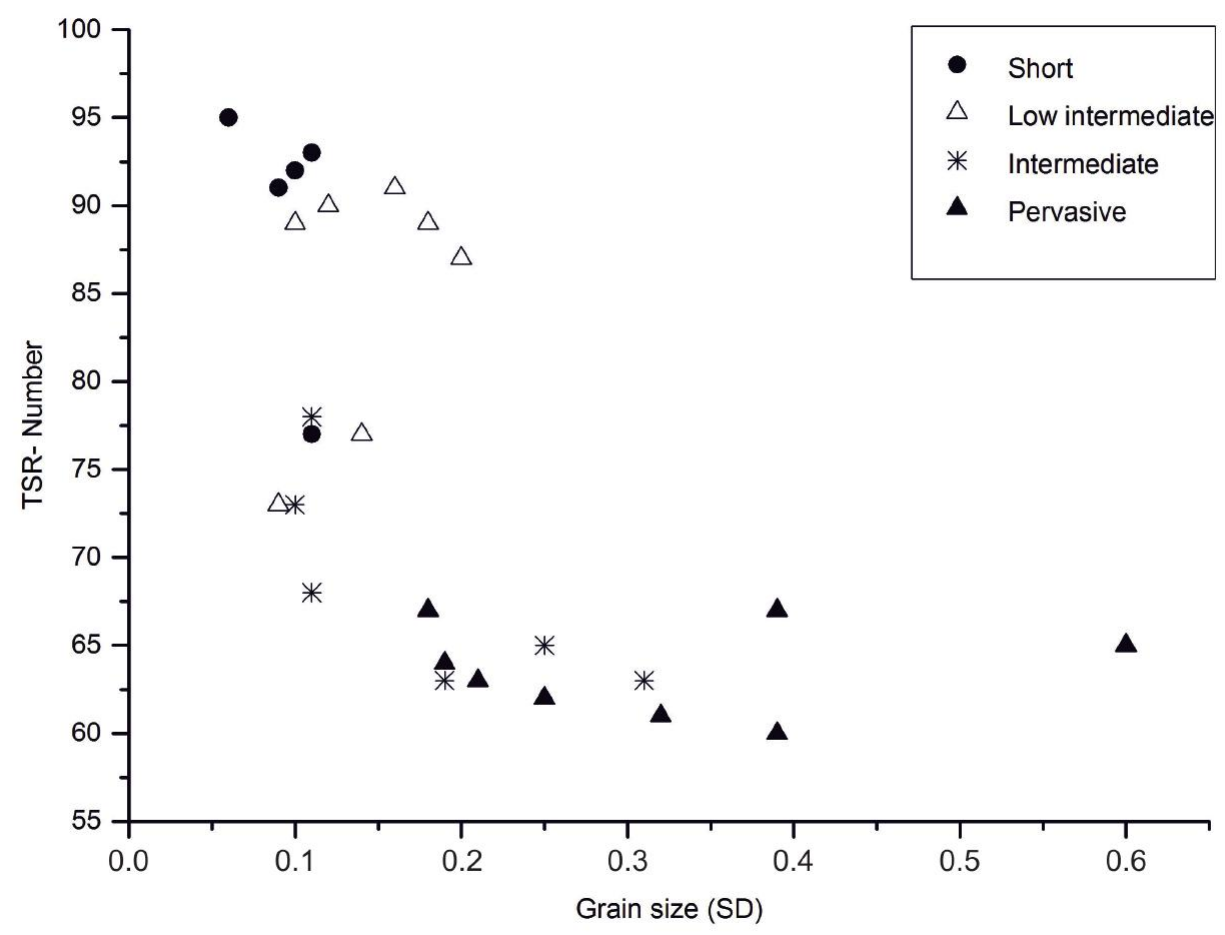

Fig 16. Grain size distribution (standard deviation) and thermal shock resistance of carbonate soapstone samples grouped by the lengths of cleavage domains. $1=\leq 1 \mathrm{~mm}, 2=$ from $>1 \mathrm{~mm}$ to $\leq 2 \mathrm{~mm}, 3=$ from $>2 \mathrm{~mm}$ to $\leq 4.0 \mathrm{~mm}, 4=>2.5 \mathrm{~cm} .4$ referred to as pervasive in the text.

consequence of the presence of sulfides was noticed in an early stage of this study, as a high sulfide concentration reduced the capacity of soapstone to resist thermal shock. However, the carbonate soapstone specimens selected to this research contain sufficiently low amounts (maximum 0.6 $\mathrm{wt} \%$ ) of sulfides that the sulfide concentration did not have a significant impact to the experimental results (Fig. 14c). Altogether, this paper demonstrates that the observed variation of the modal mineral composition in the sample set is not a significant parameter in controlling the thermal shock resistance of carbonate soapstones.

During the previous TSR tests (Kärki et al., 2013), a high amount of chlorite was discovered to have a debilitating effect on the thermal shock resistance of soapstone. As a soft mineral, chlorite deforms easily, creating pervasive and smooth foliation planes. Therefore, the TSR results of the chlorite-rich samples only indicate TSR in the chlorite-bearing foliation planes and not TSR of the whole soapstone. Very large (several centimeters in diameter) carbonate grains had also the same effect on TSR.

\subsection{Microtexture of magnesite controlling TSR}

Whether the magnesite grains are zoned or homogeneous, as illustrated in back-scattered electron images in Fig. 15, seems to have no effect on TSR of carbonate soapstones. The chemical composition of magnesite grains varies randomly and the occurrence of zoned magnesite grains does not show any consistency. 
Table 6. The standard deviations and average grain sizes in different TSR groups and types of microtexture. SD $=\mathrm{Standard}$ deviation, avg. = Average

\begin{tabular}{|c|c|c|c|c|c|c|c|c|c|c|}
\hline \multirow[t]{2}{*}{ TSR } & \multicolumn{2}{|c|}{ Granoblastic } & \multicolumn{2}{|c|}{ S/C mylonite } & \multicolumn{2}{|c|}{ Crenulation cleavage } & \multicolumn{2}{|c|}{ Porphyroblastic } & \multicolumn{2}{|c|}{ Metamorphic banding } \\
\hline & SD & avg. & SD & avg. & SD & avg. & SD & avg. & SD & avg. \\
\hline \multirow[t]{6}{*}{ HiTS } & 0.06 & 0.07 & 0.11 & 0.16 & 0.1 & 0.15 & & & & \\
\hline & & & 0.1 & 0.14 & 0.09 & 0.14 & & & & \\
\hline & & & & & 0.2 & 0.22 & & & & \\
\hline & & & & & 0.16 & 0.24 & & & & \\
\hline & & & & & 0.12 & 0.16 & & & & \\
\hline & & & & & 0.18 & 0.21 & & & & \\
\hline \multirow[t]{3}{*}{ InTS } & & & 0.09 & 0.14 & 0.11 & 0.15 & & & & \\
\hline & & & 0.11 & 0.18 & 0.14 & 0.13 & & & & \\
\hline & & & 0.1 & 0.13 & & & & & & \\
\hline \multirow[t]{5}{*}{ LoTS } & & & 0.18 & 0.14 & 0.25 & 0.15 & 0.32 & 0.2 & 0.31 & 0.35 \\
\hline & & & 0.19 & 0.2 & 0.25 & 0.1 & 0.39 & 0.2 & & \\
\hline & & & 0.19 & 0.3 & 0.11 & 0.1 & 0.39 & 0.2 & & \\
\hline & & & 0.6 & 0.1 & & & & & & \\
\hline & & & 0.21 & 0.27 & & & & & & \\
\hline
\end{tabular}

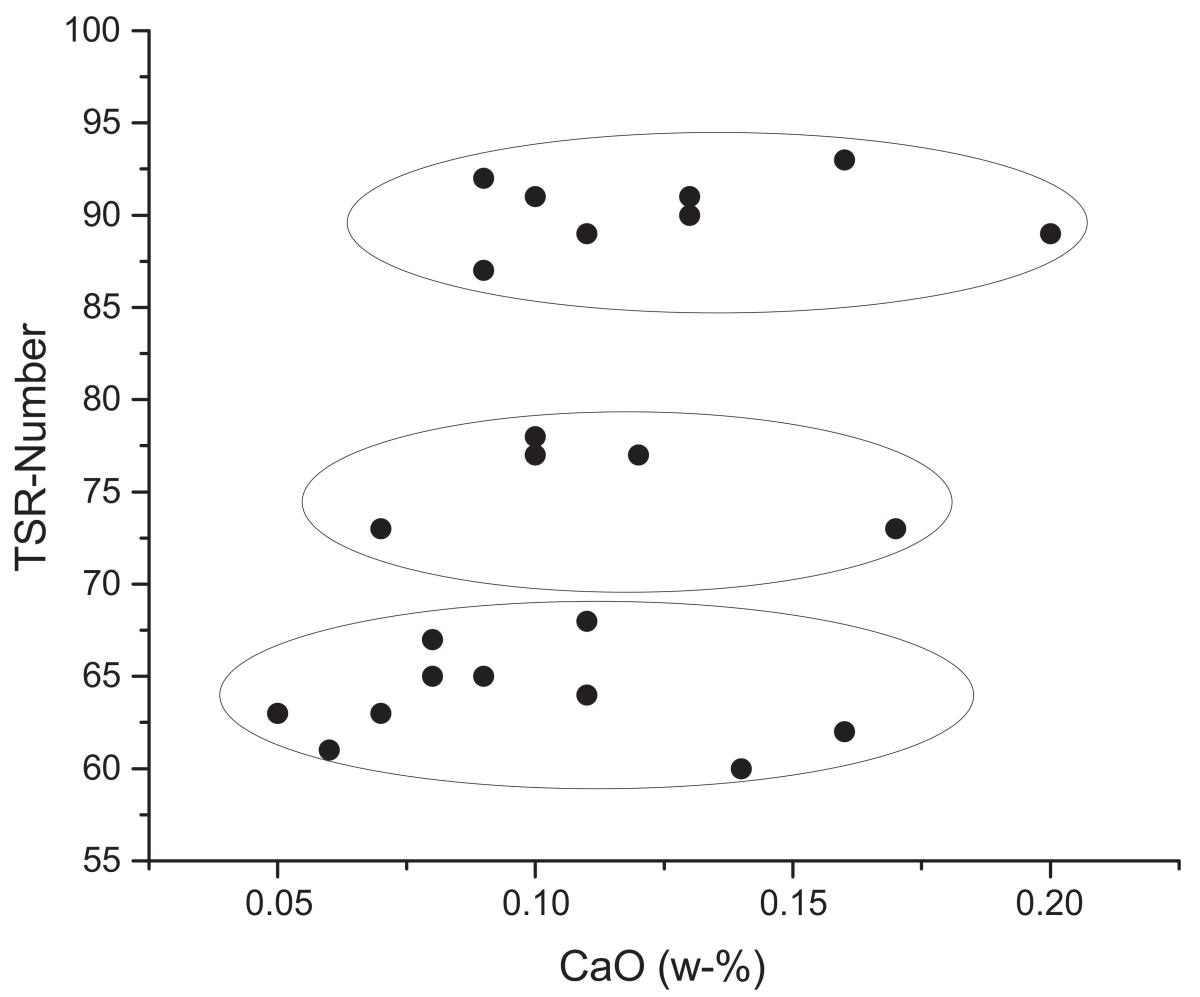

Fig. 17. Thermal shock resistance of carbonate soapstone samples vs. percentage of $\mathrm{CaO}$. 


\section{Conclusions}

Based on our experimental results, the following conclusions can be made:

- A new method for testing thermal shock resistance of soapstones has been developed. Different mineralogical and textural variations can be tested in appropriate temperatures and the results can be converted to be comparable to each other.

- Considering that all the carbonate soapstone samples tested in this study are fine grained, have a talc content of $40-60 \%$ and carbonate content of $35-50 \%$, the variable that has the greatest influence on the thermal shock resistance is secondary planar foliation.

- The major parameter controlling the thermal shock resistance of carbonate soapstones is the length of cleavage domains.

- The presence of short cleavage domains with a rough form of planarity is the most important feature in carbonate soapstones with a high thermal shock resistance.

\section{References}

Bucher, K. \& Frey, M., 1994. Petrogenesis of Metamorphic Rocks. Springer, Berlin. 319 p.

DIN 51068. 1976. Testing of ceramic materials. Determination of resistance to thermal shock. Water quenching method for refractory bricks. Part 1 . Deutsches Institut für Normung. Berlin.

Eckstrand, O.R., 1975. The Dumont Serpentinite: A model for control of nickeliferous opaque mineral assemblages by alteration reactions in ultramafic rocks. Economic Geology 70, 183-201. http://dx.doi.org/10.2113/ gsecongeo.70.1.183.

Finnish Safety and Chemicals Agency: Quarrying statistics, 2014 [e-publication]. 2014. Helsinki. [Referred 15.11.2015] Access method:

http://www.tukes.fi/Tiedostot/kaivokset/tilastot/ Tilastotiedot_vuoriteollisuus_2014.pdf

Geological Survey of Finland: Geological map of the Nunnanlahti area, updated version, 2015.

[e-publication]. 2015.

[Referred 31.3.2016] Access method: http://tupa.gtk.fi/ raportti/arkisto/22_2015.pdf
- Crenulation cleavage with a moderate intensity and incorporation of iron into talc and magnesite are also favorable for the thermal shock resistance of carbonate soapstones, although they have secondary importance comparing to the properties of cleavage domains.

- All the studied parameters have either debilitating or strengthening effect to thermal properties of carbonate soapstone. The cooperative action of these attributes determines the quality of the resistance to thermal shock.

\section{Acknowledgements}

This work was supported by K.H. Renlund Foundation, Fund for Quality Improvement of Building Products and Juhani Lehikoinen Foundation, which are gratefully acknowledged. We also thank Ferenc Molnár and Olav Eklund for their constructive and useful comments.

(in Finnish). Basic license version 1.01 [e-document] Access method:

http://en.gtk.fi/export/sites/en/disclaimer/GTK_basic_ licence_1_en.pdf

Haapala, P., 1936. On serpentine rocks in northern Karelia. Bulletin de la Commission géologique de Finlande 114, $88 \mathrm{p}$.

Havela. T., 2010.Vuolukivimateriaalin lämpörasituksen kestävyys ja arvio termisen sokin määritysmenetelmien soveltuvuudesta eri materiaalityypeille. Master's thesis. University of Oulu. p. 98. (in Finnish)

Hey. M. H., 1954. A new review of the chlorites. The Mineralogical Magazine. 30, 277-292. http://dx.doi.org/10.1180/minmag.1954.030.224.01

Howarth, D. F., 1986. Experimental study on the relationship between rock texture and mechanical performance. Transactions of the Institute of Mining and Metallurgy (Sect A Mining industry). 95, 41-45.

Kojonen, K., 1986. Prospecting in areas of glaciated terrain 1986. Geological Survey of Finland, Guide 17, 19-24.

Kuzvart, M., 1984. Industrial Minerals and Rocks. 
Developments in Economic Geology 18. Elsevier Scientific Publishing Company, Amsterdam. 454 p.

Kärki, A., Leinonen, S. \& Uusitalo, J., 2008. Soapstones - how should they be defined. International Abstract. Paper presented at the 33rd International Geological Congress (33IGC), Oslo, Norway, 6-14 August, 2008.

Kärki, A., Havela, T., Huhta, A., Jokinen, J. U. S. \& Pohjola, S., 2013. VUKEII-tutkimuskonsortio. Vuolukiven kestävä käyttö, Osa II, Vuolukiven materiaaliominaisuudet, Loppuraportti, Tekes- the Finnish Funding Agency for Innovation. 34-140. (in Finnish)

Lindahl, I. \& Nilsson, L.P., 2008. Geology of the soapstone deposits of the Linnajavri area, Hamarøy, Nordland, north NorwegianCaledonides - Norway's largest reserves of soapstone. In: Slagstad, T. (Ed.) Geology for Society, Geological Survey of Norway, Special Publication 11, 19-35.

Lindqvist, J. E., Åkesson, U. \& Malaga, K., 2007. Microstucture and functional properties of rock materials. Materials Characterization 58, 1183-1188. http://dx.doi. org/10.1016/j.matchar.2007.04.012

Lipponen, A., 2000. Metamorphism of the Saarijärvi, Mustavaara and Mustasuo ultramafic bodies in the Nunnanlahti belt and their magnetic properties. Master's thesis, University of Helsinki, 49 p. (in Finnish).

Passchier, C. W. \& Trouw, R. A. J., 2005. Microtectonics. Springer Berlin Heidelberg. 366 p.

Mc Phie, J., Doyle, M. \& Allen, F., 1993. Volcanic textures. Centre for Ore Deposits and Exploration Studies. University of Tasmania. 198p.

Pekkarinen, L.J., Kohonen, J., Vuollo, J. \& Äikäs, O., 2006. Ristiinan kartta-alueen kallioperä. Summary: PreQuaternary Rocks of the Koli map-sheet area. Geological
Map of Finland 1:100 000, Explanation to the Maps of Pre-Quaternary Rocks, Sheet 4313. Geological Survey of Finland, Espoo, 115 p. (in Finnish with English summary)

Piniazkiewicz, J., McCarthy, E.F. \& Genco, N.A., 1994. Talc, In: Carr, D.D. (Ed.), Industrial Minerals and Rocks, 6th Edition. Society for Mining, Metallurgy, and Exploration, Inc., Littleton, Colorado. 1049-1069 p.

Pohjola, S., 2013. Vuolukiven termisen sokin kestävyys ja eri määritysmenetelmien keskinäinen vertailukelpoisuus. Master`s thesis. 63 s. (in Finnish)

Rossi, T., 1997. Soapstone production at Nunnanlahti. Geological Survey of Finland, Guide 42, 44-45.

Storemyr, P., 2004. Weathering of soapstone in a historical perspective. Materials Characterization. 53, 191-207. http://dx.doi.org/ $10.1016 /$ j.matchar.2004.06.015

Wennerstrand, J.P.K., 2000. Evidence for an ophiolitic origin of the Nunnanlahti ultramafic rocks. Master's thesis, University of Helsinki, 168 p. (in Finnish).

Wiik, H.B. 1953. Composition and origin of soapstone. Bulletin de la Commission géologique de Finlande 165, $57 \mathrm{p}$.

Winter, J.D., 2014. Principles of Igneous and Metamorphic Petrology. Second edition, Pearson, Essex, 738 p.

Wise, D. U., Dunn, D. E, Engelder, J. T., Geiser, P. A., Hatcher, R. D., Kish, S. A., Odom, A. L. \& Schamel, S., 1984. Fault related rocks: Suggestion for terminology. Geology. $12,391-394$

Åkesson, U., Stigh, J., Lindquist, J. E. \& Göranson, M., 2003. The influence of foliation on the fragility of granitic rocks, image analysis and quantitative microscopy. Engineering Geology. 68, 275-288. http://dx.doi.org/ 10 .1016/ S0013-7952(02)00233-8 


\section{Appendix A. Standards of thermal shock resistance test}

Standard

ASTM C1100-88

ASTM D 116-86

BS 1902: Section 5.11: 1986

DIN 51068/Teil 1

ISO 10545-9:2013

ENV 993-11

SFS-ENV 820-3

SFS-EN 1367-5

prEN 14066
Description

Withdrawn Standard: ASTM C1 100 88(1998) Standard Test Method for Ribbon Thermal Shock Testing of Refractory Materials (Withdrawn 2005)

Standard Test Methods for Vitrified Ceramic Materials for Electrical Applications

Methods of testing refractory materials. Refractory and thermal properties. Determination of thermal spalling resistance by the prism test.

Testing of ceramic materials - Determination of resistance to thermal shock - Water quenching method for refractory bricks.

A test method for determining the resistance to thermal shock of all ceramic tiles under normal conditions of use.

Methods of test for dense shaped refractory products. Determination of resistance to thermal shock.

Advanced technical ceramics. Methods of testing monolithic ceramics. Thermo-mechanical properties. Determination of resistance to thermal shock by water quenching.

Tests for thermal and weathering properties of aggregates.

Determination of resistance to thermal shock.

Natural stone test methods. Determination of resistance to ageing by thermal shock 